\title{
Revisiting Sulphur-The Once Neglected Nutrient: It's Roles in Plant Growth, Metabolism, Stress Tolerance and Crop Production
}

\author{
Tinashe Zenda $1,2,3,4 \oplus$, Songtao Liu $1,2,3$, Anyi Dong $1,2,3$ and Huijun Duan $1,2,3, *$ \\ 1 State Key Laboratory of North China Crop Improvement and Regulation, Hebei Agricultural University, \\ Baoding 071001, China; zenda@hebau.edu.cn (T.Z.); liusongtao@hebau.edu.cn (S.L.); \\ donganyi@hebau.edu.cn (A.D.) \\ 2 North China Key Laboratory for Crop Germplasm Resources of the Education Ministry, Hebei Agricultural \\ University, Baoding 071001, China \\ 3 Department of Crop Genetics and Breeding, College of Agronomy, Hebei Agricultural University, \\ Baoding 071001, China \\ 4 Department of Crop Science, Faculty of Agriculture and Environmental Sciences, Bindura University of \\ Science Education, Bindura P. Bag 1020, Zimbabwe \\ * Correspondence: hjduan@hebau.edu.cn; Tel.: +86-139-3127-9716
}

Citation: Zenda, T.; Liu, S.; Dong, A.; Duan, H. Revisiting Sulphur-The Once Neglected Nutrient: It's Roles in Plant Growth, Metabolism, Stress Tolerance and Crop Production. Agriculture 2021, 11, 626. https:// doi.org/10.3390/agriculture11070626

Academic Editors: Pavel Krasilnikov, Miguel A. Taboada and Amanullah

Received: 28 May 2021

Accepted: 29 June 2021

Published: 3 July 2021

Publisher's Note: MDPI stays neutral with regard to jurisdictional claims in published maps and institutional affiliations.

Copyright: (c) 2021 by the authors Licensee MDPI, Basel, Switzerland. This article is an open access article distributed under the terms and conditions of the Creative Commons Attribution (CC BY) license (https:/ / creativecommons.org/licenses/by/ $4.0 /)$.

\begin{abstract}
Sulphur plays crucial roles in plant growth and development, with its functions ranging from being a structural constituent of macro-biomolecules to modulating several physiological processes and tolerance to abiotic stresses. In spite of these numerous sulphur roles being well acknowledged, agriculture has paid scant regard for sulphur nutrition, until only recently. Serious problems related to soil sulphur deficiencies have emerged and the intensification of food, fiber, and animal production is escalating to feed the ever-increasing human population. In the wake of huge demand for high quality cereal and vegetable diets, sulphur can play a key role in augmenting the production, productivity, and quality of crops. Additionally, in light of the emerging problems of soil fertility exhaustion and climate change-exacerbated environmental stresses, sulphur assumes special importance in crop production, particularly under intensively cropped areas. Here, citing several relevant examples, we highlight, in addition to its plant biological and metabolism functions, how sulphur can significantly enhance crop productivity and quality, as well as acclimation to abiotic stresses. By this appraisal, we also aim to stimulate readers interests in crop sulphur research by providing priorities for future pursuance, including bettering our understanding of the molecular processes and dynamics of sulphur availability and utilization in plants, dissecting the role of soil rhizospherical microbes in plant sulphur transformations, enhancing plant phenotyping and diagnosis for nutrient deficiencies, and matching site-specific crop sulphur demands with fertilizer amendments in order to reduce nutrient use inefficiencies in both crop and livestock production systems. This will facilitate the proper utilization of sulphur in crop production and eventually enhance sustainable and environmentally friend food production.
\end{abstract}

Keywords: sulphur; crop productivity; crop quality; sulphate transporters; secondary sulphur compounds; abiotic stress tolerance; crop production

\section{Introduction}

Realizing the mounting global demand for adequate and highly nutritious food as well as fiber for the rising human population, there is a need to increase global crop production [1]. One way for improving crop production and productivity is through modifying soil nutrient supply, among other strategies [2]. Sulphur, (S) macronutrient, essential for plant growth and development [3-7], has also been acknowledged for improving crop productivity [8-13], quality [14-16], and plants' abiotic stress responses [17-22]. Therefore, access to an adequate supply of $S$ for plants throughout their development is necessary for 
optimum crop performance [23]. Despite all this, however, $\mathrm{S}$ macronutrient has received little attention for many years, until only recently $[17,24]$. This is largely because, previously, it was thought fertilizers and atmospheric deposition adequately supplied the soil with enough of the nutrient $[9,25]$. Consequently, little crop research on $\mathrm{S}$ nutrient has been conducted and very scarce information has been reported [9,17].

However, remarkable revelations indicate that most arable soil around the world has been deficient in $S$ for over three decades, but the negative effects on global crop production have only recently become evident $[4,12,26]$. In recent years, diminished atmospheric $S$ deposition as a result of stricter emission regulations, decreased use of $S$ based fungicides, use of high analysis low $\mathrm{S}$ synthetic fertilizers, low $\mathrm{S}$ returns from farm animal derived manure, cultivation of high nutrient-demanding and high yielding crop cultivars, and intensification of agriculture have all led to widespread S shortage across the globe [17]. Subsequently, due to the importance of $S$ nutrient in plant functions (such as in sugar production, carbon dioxide assimilation, nitrogen $(\mathrm{N})$ fixation and protein formation), $\mathrm{S}$ nutrient is increasingly becoming more important [13]. Notably, scientific research indicates that the crop farmers will have to start applying $S$ nutrient through fertilization to achieve optimal production from ever-improving, high performance genetics [24].

Thus, the re-emerging interest in $\mathrm{S}$ has recently spurred its global demand. In terms of market, the need for $\mathrm{S}$ fertilizers is increasing at a considerable rate [27], with the global S fertilizer market accounting for US $\$ 4.52$ billion in 2017 and expected to reach US $\$ 7.03$ billion by 2026 [28]. This is largely driven by an upsurge in demand in the agriculture sector for crops prone to $S$ deficiency and need for higher productivity. In addition, the degradation of soil quality and increase in $S$ deficiency in the soil, reduction in $\mathrm{S}$ emission influencing the requirement for added $\mathrm{S}$, surge in use of sulphur in fungicides and insecticides are the drivers to the growth of the $S$ market [28]. By type, elemental $S$ segment is expected to be the fastest growing during the forecast period. Particularly, the use of elemental $\mathrm{S}$ is increasing due to its ability to reduce soil $\mathrm{pH}$ and to reclaim sodic soils. By crop type, the oilseeds and pulses (especially canola and soybean (Glycine max L.) segment will dominate the high $S$ requirements, largely owing to the fact that $S$ enhances oil synthesis and protein production in pulses [29]. Further projections show that the Asia Pacific region will be the fastest-growing market during the forecast period 2017-2026, being driven by the increase in agricultural practices and the requirement for high-quality agricultural produce [30], with the Chinese fertilizer demand playing a major role [31].

In crop production, $S$ is attracting the most attention in soil science and plant nutrition due to its good nutritive potentiality to crops, its potential protective role to abiotic stresses, and its relative immobility in the soil-plants system [32,33]. It has been observed that, without adequate $S$, crops cannot reach their full potential in terms of yield, quality or protein content, nor can they make efficient use of applied $\mathrm{N}$, caused by the $\mathrm{S}$ requirement for protein and enzyme synthesis $[4,10,17,34]$.

In the wake of huge demand for high quality cereal and vegetable diets, $\mathrm{S}$ can play a key role in augmenting the production, productivity, and quality of crops [35,36]. Moreover, in light of emerging problems of soil fertility exhaustion, $\mathrm{S}$ assumes special importance for crop production, particularly under intensively cropped areas. In this review, therefore, we discuss the role of $S$ nutrient in crop production, particularly focusing on plant growth, metabolism and acclimation to abiotic stresses, as well as improving crop productivity. We then conclude by highlighting the future prospects of $S$ research in crops.

\section{Biological Functions of Sulphur (S) in Plants}

Sulphur is an essential macronutrient, vital for plant growth and functioning; ranked fourth after nitrogen, phosphorus $(\mathrm{P})$ and potassium (K); with total S content in plant tissues ranging from $0.3 \%$ to $7.6 \%[3,36]$. Precisely, $\mathrm{S}$ is of great importance for the primary structure of proteins and functioning of enzymes, by being a constituent of the amino acids cysteine (Cys) and methionine (Met) [21,37-40]. The structural compositions of these essential $\mathrm{S}$ containing amino acids are shown in Figure 1. 


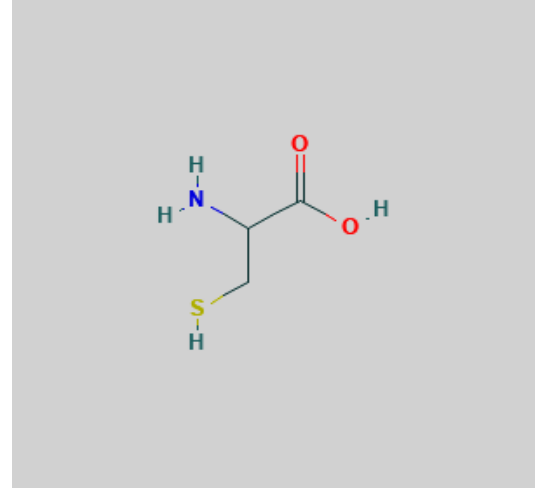

(a)

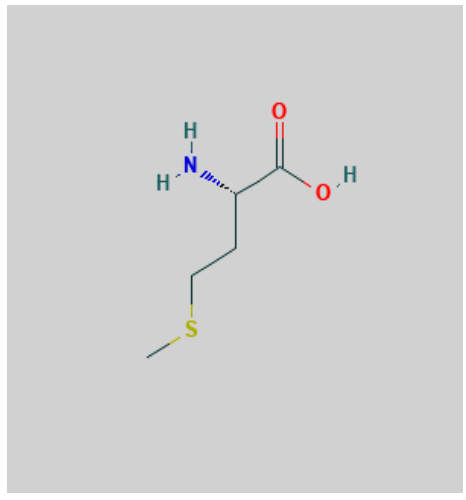

(b)

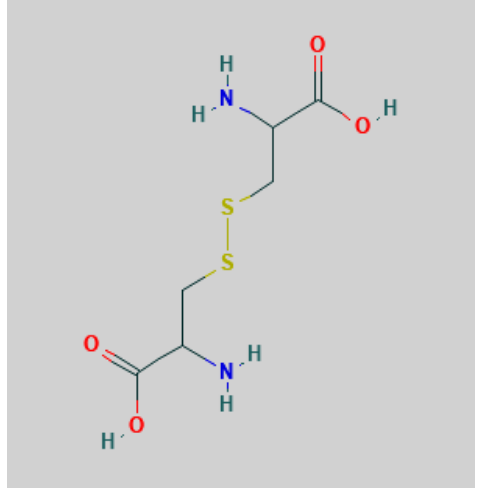

(c)

Figure 1. Structural constituents of essential sulphur containing amino acids: (a) Cysteine; (b) methionine; (c) cystine. Note: cystine comprises two cysteine molecules linked together by an S-S (sulphur-sulphur) bond.

Sulphur is also a component of oligopeptides (glutathione; GSH), vitamins and cofactors [9], a variety of secondary plant products such as glucosinolates in Cruciferae and alliins in Liliaceae $[16,17,23,33]$ and a key ingredient in chlorophyll [3]. Therefore, $\mathrm{S}$ plays critical roles in the catalytic or electrochemical function of the biomolecules in cells $[32,33]$. Generally, in phototrophic organisms, the redox properties of S element in proteins and in S-containing metabolites are essential as crosslinks between the reductive assimilation processes of photosynthesis and reactive oxygen species (ROS) that are produced as by-products of electron transport chains. Besides, the catalytic abilities of reduced $S$ are documented in the cofactors and ligands coenzyme A, biotin, lipoic acid, thiamin, etc. [36,41]. In proteins, the structural role of disulfide bridges in plant g-glutamylCys ligase, which is the first enzyme of GSH biosynthesis, is well acknowledged. The regulatory functions of these disulfide bridges in plants are more significant in enzymes of the Calvin cycle [41].

Moreover, the essential role of $\mathrm{S}$ element in $\mathrm{N}$ metabolism is well recognized. Since plants use $\mathrm{N}$ and $\mathrm{S}$ jointly to biosynthesize proteins, inadequacy of $\mathrm{S}$ may lead to ineffective utilization of the plant's $N$ content $[4,13,17,42]$. Besides, $S$ metabolites such as GSH offer plant protection against oxidative stresses emanating from heavy metals and xenobiotics $[17,20-22]$. Further, $\mathrm{S}$ enhances crop yield and product quality $[16,17,23,43,44]$. Sulphur influences the colour and fragrance of flowers and vegetables, and affects crop yield, taste, and aroma of foodstuffs such as cruciferous vegetables, garlic (Allium sativum L.), and onion (Allium cerpa L.) $[16,24,26]$. The yield and quality or nutritive importance of S nutrient in crop plants has been observed in bread wheat (Triticum aestivum L.) $[10,38,45]$, barley $[19,25]$, canola oil rapeseed [6,44], green house tomato [46], soybean [11,45], sunflower (Helionthus annus L.) [12], onion [14,15], garlic [47], spinach and pepper [48], and mustard (Brassica juncea L.) [49].

\section{Sulphur in the Soil}

Soil sulphur exists as organic sulphur compounds, sulphide $\left(\mathrm{S}^{2-}\right)$, elemental sulphur $\left(\mathrm{S}^{0}\right)$, and sulphate $\left(\mathrm{SO}_{4}{ }^{2-}\right)[34,50,51]$. It is transformed between these forms via processes of mobilization, mineralization, immobilization, oxidation, and reduction. Up to $98 \%$ of the total soil sulphur occurs in form of organic sulphur compounds, and comprises a heterogeneous mixture of plant residues, animal manures, and soil microbes [17,45]. It is not directly accessible to plants until it undergoes mineralisation by micro-organisms to release $\mathrm{SO}_{4}{ }^{2-}$ for plant uptake $[23,32,45]$. 
The rates of mineralisation and immobilisation are determined by the factors that govern micro-organisms growth, including soil water, temperature, $\mathrm{pH}$, and availability of other nutrients. As such, available soil sulphur varies throughout the year [23]. Studies suggest that the soil microbiological biomass $S$ generally accounts for $1.5-5 \%$ of total soil organic $S$, with proteins and amino acids being the major $S$ form in microbial cells. Meanwhile, microbiological biomass is relatively labile and believed to be the most active pool for S turnover in the soil. Generally, the application of soil organic matter (SOM) increases the microbiological biomass including microbial S [17]. Meanwhile, in acidsulphate soils, $\mathrm{S}^{2-}$ can predominate, and significant $\mathrm{SO}_{4}{ }^{2-}$ can be present in arid soils or soils where large additions of gypsum have been made [23]. However, plants cannot absorb or utilize organic $\mathrm{S}$ or $\mathrm{S}^{2-}$, until it is transformed to the $\mathrm{SO}_{4}{ }^{2-}$ form [36].

Sulphate is the most popular form of inorganic $S$, categorized into soil $\mathrm{SO}_{4}{ }^{2-}$, adsorbed $\mathrm{SO}_{4}{ }^{2-}$ and mineral S [52,53]. Inorganic $\mathrm{S}$ is usually much less $(10 \%$ or less of total soil S) abundant in most of the agricultural soils than is organically bound $S[45,54]$. In soil solution, $\mathrm{SO}_{4}{ }^{2-}$ is highly mobile and only weakly held on colloidal particles; it is easily leached out of the crop rhizospheres and pastures, and huge losses of up to $100 \mathrm{~kg} \mathrm{~S} \mathrm{ha}^{-1}$ per year have been recorded in Southern England [23]. Sulphur may precipitate in the form of $\mathrm{SO}_{4}{ }^{2-}$ as $\mathrm{CaSO}_{4}{ }^{2-}, \mathrm{MgSO}_{4}{ }^{2-}$, or $\mathrm{Na}_{2} \mathrm{SO}_{4}$. Sulphur can also be present in waterlogged soils as $\mathrm{S}^{2-}$ which is transformed to plant available $\mathrm{SO}_{4}{ }^{2-}$ when the soils dry out [55]. Wetlands may accumulate huge amounts of sulphide metals such as pyrite $\left(\mathrm{FeS}_{2}\right)$, and upon draining these areas, the $\mathrm{S}$ compounds are oxidized to $\mathrm{SO}_{4}{ }^{2-}$, accompanied by a decrease in $\mathrm{pH}$ [55]. If adsorbed $\mathrm{SO}_{4}{ }^{2-}$ in the soil is not readily available to plants, any treatment causing a decrease in retention and a corresponding increase of $\mathrm{SO}_{4}{ }^{2-}$ in soil solution should increase $\mathrm{SO}_{4}{ }^{2-}$ availability to plants. The higher concentration of $\mathrm{SO}_{4}{ }^{2-}$ in the soil solution of the uppermost soil layer may also be caused by the application of $S$ containing fertilizers and other $S$ inputs. It is also believed that subsoil plant residues adsorbs more $\mathrm{SO}_{4}{ }^{2-}$ as compared to surface soil material since $\mathrm{SO}_{4}{ }^{2-}$ adsorption sites tend to be blocked by SOM and phosphate accumulations [17,51].

$\mathrm{SO}_{4}{ }^{2-}$ is also taken into microorganisms and plants to become fixed, and then transformed into SOM. Diverse soil microbial enzymes play key biochemical functions in the process of SOM decomposition, and their activity can be used as an index of the changes in the intensity level of soil biological processes, and is usually correlated with SOM physical and chemical properties [56,57]. The process of mineralization of sulfur-containing organic compounds and their transformation into bioavailable forms is catalysed by specific enzymes, including arylsulfatase sulphohydrolase (AR) (EC 3.1.6.1.), rhodanese (or thiosulphate reductase) (RD) (EC 2.8.1.1), and transferases [50,57]. AR enzyme catalyzes the hydrolysis of aromatic sulfate esters to inorganic $\mathrm{SO}_{4}{ }^{2-}$ by splitting the O-S bond (reviewed in Scherer et al. [45]). Moreover, AR is linked to SOM content, and its activity diminishes with an increase in soil profile depth, with soil moisture and temperature also determining enzyme activity rate [58]. RD catalyzes the indirect oxidation of thiosulphate $\left(\mathrm{S}_{2} \mathrm{O}_{3}{ }^{2-}\right)$ to $\mathrm{SO}_{4}{ }^{2-}$ in the soil, and its activity occurs in a wide range of soils [56,59]. RD enzyme can function as $\mathrm{S}_{2} \mathrm{O}_{3}{ }^{2-}$ sulphur transferase and release sulphite $\left(\mathrm{SO}_{3}{ }^{2-}\right)$ and $\mathrm{S}^{2-}$ when suitable reduced thiol acceptors like GHS or dihydrolipoic acid are present [60]. Meanwhile, the assimilation of $\mathrm{SO}_{4}{ }^{2-}$ to organic $\mathrm{S}$ in the soil micro-flora through the process of immobilization temporarily diminishes $\mathrm{SO}_{4}{ }^{2-}$ availability to plants [23]. An illustration in Figure 2 gives a schematic representation of the processes and dynamics involved in the cycling of $S$ across the atmospheric, soil, plant, and animal systems. 


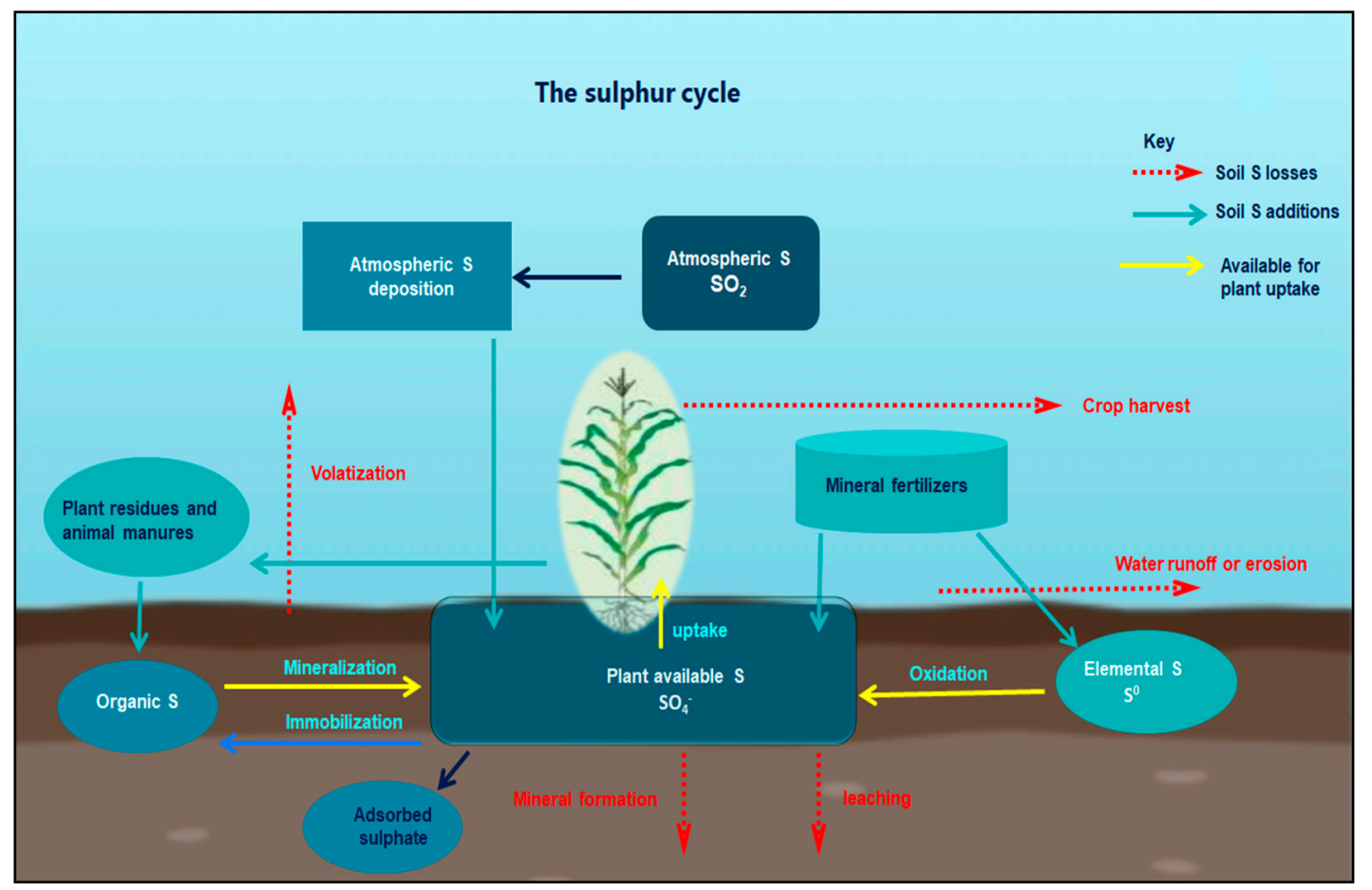

Figure 2. A simplified systematic representation of the sulphur (S) cycle (Adopted from https://www.nutrien-ekonomics. com accessed on 16 January 2021). Atmospheric $\mathrm{S}\left(\mathrm{SO}_{2}\right)$ arises from burning $\mathrm{S}$ containing fossils, volcanic emissions and other natural processes. $\mathrm{SO}_{4}{ }^{2-}$ and sulphuric acid are deposited back on the earth through precipitation. Atmospheric deposition exists as dust settling on plants, emanating from mineral mining and rock erosion. Organic $\mathrm{S}$ becomes available when SOM is mineralized to $\mathrm{SO}_{4}{ }^{2-}$. Addition of mineral $\mathrm{S}$ fertilizers $\left(\left(\mathrm{NH}_{4}\right)_{2} \mathrm{SO}_{4}, \mathrm{CaSO}_{4}{ }^{2-}, \mathrm{K}_{2} \mathrm{SO}_{4}, \mathrm{ZnSO}_{4}, \mathrm{MgSO}_{4}\right.$, $\mathrm{S}^{0}, \mathrm{SSP}$, etc) to the soil improves the readily available soil $\mathrm{S}$ pool for plant uptake. The unharvested plant material and reused plant/agricultural residues return $S$ back into the soil in an organic form. Animal manure and other biosolids also provide organic $S$ into the soil, with the $S$ quantity in such materials depending on the animal species, age and diet fed upon. Organic $\mathrm{S}$ must be mineralized to provide $\mathrm{SO}_{4}{ }^{2-}$ to the plants. Plant residual derived $\mathrm{S}$ becomes available only when residues are decomposed by soil microbes. $\mathrm{S}^{0}$ needs biological oxidation, by means of several $\mathrm{S}$ oxidizing bacteria, to be transformed into plant available $\mathrm{SO}_{4}{ }^{2-}$. Sulphur losses can be encountered through several processes. The loss of $\mathrm{S}$ through volatilization is quite small ( $<0.05$ percent of total soil S). $\mathrm{SO}_{4}{ }^{2-}$ may be leached out of the root zone due to excess rainfall or may accumulate at the soil surface in dry conditions. Under certain specific conditions, mineral formation processes may cause $\mathrm{S}$ to form relatively insoluble mineral complexes $\left(\mathrm{CaSO}_{4}{ }^{2-}, \mathrm{feSO}_{4}{ }^{2-}\right.$, etc.). Surface losses of $\mathrm{S}$ can occur via runoff when $\mathrm{SO}_{4}{ }^{2-}$ is localized near the soil surface during high intensity rainfall events or via erosion when soil sediment is lost through erosion. The plant metabolic $\mathrm{SO}_{4}{ }^{2-}$ is harvested in seeds and other plants products. Detailed explanations to $\mathrm{S}$ cycle can be obtained from Till [34] and Eriksen et al. [51].

\section{Sulphur in the Plant System}

\subsection{Uptake, Assimilation and Metabolism of S by Plants}

Plants have evolved a network of sulphate transporters with different affinity, localization, and regulation, enabling efficient uptake and distribution of $S$ from the root cells into sink organs according to the availability of $S$ and plant's requirements [16,18,61-63]. Although atmospheric $\mathrm{SO}_{2}$ is taken up and utilized by the aerial parts of higher plants, the most important source of $\mathrm{S}$ is $\mathrm{SO}_{4}{ }^{2-}$ anions from the soil or fertilizer taken up by the roots $[9,50,64,65]$. Additionally, the uptake and assimilation of $\mathrm{SO}_{4}{ }^{2-}$ is strongly regulated at the transcription level $[18,32,33]$. In the physiological $\mathrm{pH}$ range, the divalent $\mathrm{SO}_{4}{ }^{2-}$ anion is taken up by root cells and then transported in the xylem and phloem, with transmembrane transport steps catalysed by a family of $\mathrm{SO}_{4}{ }^{2-}$ transporters $[3,16,33]$. Plant $\mathrm{S}$ uptake and assimilation have been extensively described and several transporter genes involved in these acquisition and assimilation processes identified [66-71]. The rise in sulfate uptake capacity is a typical response to sulfate limitation. This rise is primarily 
elicited by transcriptional regulation of two high affinity root localized and expressed sulfate transporters, SULTR1 and SULTR1 [39,66]. When S is resupplied, the transcript levels of these transporters will be rapidly repressed [39].

The sulphate assimilation pathway essentially provides plants with Cys which is further utilized for protein synthesis and as a source of reduced $\mathrm{S}$ for the biosynthesis of Met, GSH, coenzymes, and different secondary $S$ compounds [69,72]. The assimilation of $\mathrm{S}$ requires transport into the cell and then organelles via $\mathrm{SO}_{4}{ }^{2-}$ transporters, activation by adenylation to produce adenosine $5^{\prime}$-phosphosulfate (APS), which is catalysed by ATP sulfurylase (ATPS), and subsequent reduction of APS to $\mathrm{SO}_{3}{ }^{2-}$ by APS reductase (APR) $[62,63,73]$. Thus, ATPS catalyzes the first critical step in the sulfate assimilation pathway, which is the activation of sulfate prior to its reduction [71]. In polluted environments, some $\mathrm{S}$ may also be taken up by leaves as gaseous sulphur dioxide $\left(\mathrm{SO}_{2}\right)$ or hydrogen sulfide $\left(\mathrm{H}_{2} \mathrm{~S}\right)$ and assimilated into Cys $[18,23]$, and in sensitive plants, $\mathrm{SO}_{2}$ can be phytotoxic at relatively low atmospheric concentrations $\left(0.1 \mathrm{mg} \mathrm{m}^{-3}\right)$ [3].

In a more recent review, Kopriva et al. [16] highlighted that $\mathrm{SO}_{4}{ }^{2-}$ assimilation is tightly regulated according to demand. In the periods of low $\mathrm{SO}_{4}{ }^{2-}$ availability, plants increase $\mathrm{SO}_{4}{ }^{2-}$ transport and the rate of reduction. This means that the pathway is repressed under normal levels of external $\mathrm{SO}_{4}{ }^{2-}$ and derepressed by $\mathrm{SO}_{4}{ }^{2-}$ starvation or by excessive $\mathrm{S}$ demand for growth and development $[74,75]$. Moreover, even the repressed pathway can be further reduced when reduced $\mathrm{S}$ is availed to the plant [72]. External $\mathrm{SO}_{4}{ }^{2-}$ conditions have a direct influence on the process of $\mathrm{SO}_{4}{ }^{2-}$ uptake within the plant system. The pathway is down-regulated when plants are offered reduced $\mathrm{S}$ compounds, e.g., $\mathrm{Cys}, \mathrm{GSH}, \mathrm{SO}_{3}{ }^{2-}$, or $\mathrm{H}_{2} \mathrm{~S}$, or when nitrate or carbon is limited. Further, Giordano and Raven [21] highlighted that $S$ uptake and primary assimilation are induced by its limitation, light, carbohydrates, or amino acids, as well as by oxidative stress and other conditions which trigger increased demand.

S-containing metabolites function directly as constituents of proteins and enzymes, or indirectly as cofactors, methyl group donors, prosthetic groups, and hormone precursors [76]. Metabolism of $\mathrm{SO}_{4}{ }^{2-}$ is initiated by its activation by the reaction of adenylation catalysed by ATPS enzyme. ATP is limiting $S$ uptake, as it's over expression enhances $\mathrm{S}$ uptake by plants [18]. In the final step of $\mathrm{SO}_{4}{ }^{2-}$ assimilation, $\mathrm{SO}_{3}{ }^{2-}$ is reduced to $\mathrm{S}^{2-}$ by sulphite reductase (SiR). $\mathrm{S}^{2-}$ is then transferred to activated serine by O-acetylserine (thiol) lyase (OASTL) to form Cys [65]. The formation of Cys is a reaction in which the pathway merges with assimilation of $\mathrm{N}$ and carbon in plants $[18,64]$.

Cys is the first organic compound synthesized in the $\mathrm{SO}_{4}{ }^{2-}$ assimilatory pathway, after the reduced $\mathrm{S}^{2-}$ is incorporated into activated serine, O-acetylserine, thus linking glycine-serine metabolism to $S$ metabolism $[16,50,52]$. Cys is an important amino acid incorporated into various proteins, and a precursor of numerous essential compounds such as Met, S-adenosylmethionine (SAM), S-methylmethionone, iron-S clusters, hormones, vitamins, and enzyme cofactors [18]. Disulphide bonds formed in proteins between the thiol groups of Cys residues play crucial roles in forming and maintaining the tertiary structure of proteins. Besides the synthesis of proteins and Met derivatives, Cys also serves as a building stone for all further derived reduced $S$ containing compounds such as GSH, phytochelatines, S-methylCys, S-alkyleysteine, glucosinolates and phytoalexins [16]. Organic compound containing $S$ are also responsible for the specific taste and smell of onion, garlic, herbs, and other valuable vegetables used in the kitchen and traditional medicine. Further degradation of Cys is catalysed by Cys desulfhydrase and results in pyruvate, ammonia, and $\mathrm{H}_{2} \mathrm{~S}$ production. The released $\mathrm{H}_{2} \mathrm{~S}$ might play a role in plant defense upon pathogen attack $[17,36]$.

\subsection{Physiological and Metabolic Alterations in Plants under S Deprivation}

Sulphur starvation results in decreased crop yields and quality; in addition to various phenotypically visible alterations. Nutritional stress of $\mathrm{S}$ most notably modulates $\mathrm{SO}_{4}{ }^{2-}$ assimilation. Upon deprivation, $\mathrm{S}$ is remobilized and the efficiency of the remobilization of 
vacuole stored $\mathrm{SO}_{4}{ }^{2-}$ and other pools of reduced $\mathrm{S}$ can be lower than $\mathrm{N}$, so that during later growth or grain filling, low tissue $\mathrm{S}$ contents may result. Typically, therefore, the symptoms of $S$ deficiency occur first in the younger tissues and are seen as interveinal yellowing of leaves in wheat, maize, and rice $[9,23]$. In sorghum, cabbage, and cotton, $S$ deficiency manifests as the reddening of stems and leaf edges, reddening and purpling of leaves, and reddening of petioles, respectively (for detailed review, see Tiwari and Gupta [9]). S-deprived plants exhibit stunted growth and chlorosis, and sometimes turn reddish [33], accumulation of anthocyanins, bending of the leaf blade, and enhanced root growth $[4,52]$. These symptoms are also partially shared by other nutrient stresses, such as nitrate, or phosphate starvation, which already indicates that distinct stresses might, in part, use common signalling pathways with specific response-control elements providing specificity. However, for easy differentiation, symptoms of $\mathrm{N}$ deficiency are more obvious in the older tissues first, whereas $\mathrm{S}$ deficiency symptoms are more apparent in younger leaves (since $\mathrm{S}$ is less mobile in plant system) and can be visible early in the season [23].

Sulphur deprivation results in the contents of $\mathrm{SO}_{4}{ }^{2-}$ and S-containing compounds such as Cys, Met and GSH being decreased. Protein synthesis is repressed, and hence, the contents of the soluble $\mathrm{N}$ pools, such as nitrate and amides, increase [77]. The S storage pool is remobilized and the amount of S-rich seed storage proteins decreases, whereas that of S-poor seed storage proteins increases to compensate for the reduction of total proteins in seeds [52]. Owing to the storage of $\mathrm{SO}_{4}{ }^{2-}$ in the vacuole and the presence of a pool of thiol compounds, such as GSH, the development of symptoms is a slow and gradual process. Therefore, it is assumed that various local, systemic, and time-dependent regulation steps occur in a series of responses. Since the primary site of $\mathrm{SO}_{4}{ }^{2-}$ uptake is the root, but the major site of reduction and biosynthetic need is the leaf, it has to be further assumed that the evolution of the signalling mechanisms is in both directions $[52,63]$.

As already highlighted above, during the periods of low $\mathrm{SO}_{4}{ }^{2-}$ availability, plants increase $\mathrm{SO}_{4}{ }^{2-}$ transport and the rate of reduction. Similarly, APR is induced when GHS levels are low. This emphasizes that GHS synthesis also occurs in demand driven manner under abiotic stresses to scavenge ROS [18]. Sulphate withdrawal from the growing medium decreases the levels of $\mathrm{SO}_{4}{ }^{2-}$, Cys, and GHS in plant tissues, leading to the induction of $\mathrm{SO}_{4}{ }^{2-}$ transporter systems and key enzymes along the assimilatory pathway [61]. The increase in steady-state levels of mRNAs for high-affinity $\mathrm{SO}_{4}{ }^{2-}$ transporters, ATPs, and APR upon S starvation is detected by Northern blot analysis or CDNA arrays, and it is disclosed that modulation of the de-repression occurs at the transcription level. This de-repression correlates with the time of exposure to S-deficiency. When plants are supplied with $\mathrm{SO}_{4}{ }^{2-}$ again, the activity of APR and ATPS quickly returns to the normal levels [18,52]. Moreover, Kawashima and co-workers highlighted that $S$ starvation induces the expression of microRNA-395 and one of its target genes in different cell types [78]. Further, primary and secondary metabolic pathways, involving amino acids, carbohydrates, and glucosinolates, are modulated in response to $S$ deficiency stress [18]. Particularly, the assimilated $S$ can be stored in form of glucosinolates and is remobilized in the event of acute $\mathrm{S}$ deficiency. Expanded integrated omics studies would aid in elucidating the holistic networks of $\mathrm{S}$ metabolism.

\section{Interaction of $\mathbf{S}$ with Other Nutrients}

\section{1. $S$ and Nitrogen $(N)$ Interaction}

In plants, $\mathrm{S}$ and $\mathrm{N}$ play a synergistically central role in the synthesis of proteins, and the supplies of these nutrients in plants are highly inter-related [17,34]. $S$ requirement and metabolism in plants are closely related to $\mathrm{N}$ nutrition, and $\mathrm{N}$ metabolism is also strongly affected by the $S$ status of the plant. As is the case with the carbon assimilation pathway that is closely linked to nitrate assimilation in plants, $\mathrm{S}$ and $\mathrm{N}$ assimilatory pathways are also intertwined, with the abundance of one element modulating the other [20]. Various researchers $[4,10,17,79]$ have reported a lack of $S$ to limit the efficient utilization of added soil $\mathrm{N}$. Thus, for maximal use of added N, sulphur addition to the soil becomes essential. 
For instance, the ideal ratio of available $\mathrm{N}$ to available $\mathrm{S}$ has been shown to be $7: 1$, with the ratio $<7$ resulting in decreased oil rapeseed yields [80]. Additionally, field-grown oil rapeseed with mustard crop recovered $27-31 \%$ of added $\mathrm{S}$ in the absence of $\mathrm{N}$, but $37-38 \%$ with $60 \mathrm{~kg} \mathrm{ha}^{-1} \mathrm{~N}$ [17]. For optimum plant growth and development, ideal N:S ratios for different crop species have been suggested, as presented in Table 1.

Table 1. N:S ratios in plant tissues of different crops.

\begin{tabular}{ccc}
\hline Crop Species & N:S Ratio & Reference \\
\hline Cereals & $10: 1$ & {$[81]$} \\
Maize & $15.6: 1$ & {$[82]$} \\
Wheat & $7.1: 1$ & {$[82]$} \\
Oil rapeseed & $5: 1$ & {$[81]$} \\
Oil rapeseed & $7: 1$ & {$[80]$} \\
Mustard & $3.1: 1$ & {$[81]$} \\
Grassland-grazing & $8-12: 1$ & {$[81]$} \\
Potato (Solanum tuberosum L.) & $10.1: 1$ & {$[81]$} \\
Potato & $12: 1$ & {$[83]$} \\
Groundnut & $14.8: 1$ & {$[82]$} \\
\hline
\end{tabular}

Both $\mathrm{S}$ and $\mathrm{N}$ interact to affect uptake and nutrient use efficiency of each by plants [20]. A study by Fismes et al. [84], using field grown oil rapeseed, showed that $S$ deficiency can reduce nutrient use efficiency and that $\mathrm{N}$ deficiency can also reduce $\mathrm{S}$ use efficiency. Moreover, Anjum et al. [20] revealed beneficial effects related to oilseed brassicas' tolerance to different abiotic stresses, emanating from the positive $\mathrm{S}$ and $\mathrm{N}$ interaction. Besides, limiting $S$ supply to crops depresses the utilization of available soil $\mathrm{N}$, leading to increased nitrate leaching [4]. S and $\mathrm{N}$ relationships have also been established in terms of dry matter accumulation and yield in different crop species [8,17,85-88]. Grain yield ha ${ }^{-1}$ can $^{-1}$ be significantly boosted by applying $\mathrm{N}$ and $\mathrm{S}$ [13], whilst at the whole plant level, the requirement for matching $\mathrm{N}$ and $\mathrm{S}$ supply to corresponding demand arise from the close link between the uptake of $\mathrm{SO}_{4}{ }^{2-}$ and $\mathrm{NO}_{3-}$ [89]. Since $\mathrm{S}$ and $\mathrm{N}$ are both required for the protein synthesis, the ratio of total $\mathrm{N}$ to total $\mathrm{S}$ in plant tissue can reflect the ability of $\mathrm{N}$ and $\mathrm{S}$ in protein synthesis [42]. Therefore, an altered ratio of reduced $\mathrm{N}$ to reduced $\mathrm{S}$, an acceptable way to reflect the amount of amino acids $S$, may reveal significant protein metabolism alterations that may have important implications for protein quality [17].

$\mathrm{N}$ and $\mathrm{S}$ have exhibited strong interdependence on effecting significant yield and quality improvements in several crop species, including in field maize (Zea mays L.) $[8,13]$, oil rapeseed (Brassica napus L.) [85,86], oilseed crops [9,90], soybean [87], groundnut [88], wheat [91], sunflower [92,93], and sesame (Sesamum indicum L.) [94]. In their field study on maize, Ali et al. [13] revealed a significant positive effect of $\sim 32 \%$ on harvest index, as a result of the $\mathrm{N}$ and $\mathrm{S}$ synergistic interaction. However, the interaction had no significant effect on 1000-grain weight. Xie et al. [8] showed that the interaction of $\mathrm{N}$ and $\mathrm{S}$ had a significant positive influence of about $187 \%$ on yield in maize. The grain protein content markedly increased by $0.65 \%$, whilst that for the total amino acid, soluble sugar, and crude fat increased by $6.68 \%, 7.19 \%$, and $7.09 \%$, respectively, as compared to the control in one of the varieties LY16. However, there was no significant interaction found between $S$ and $\mathrm{N}$ in increasing starch content [8]. In another study, application of $40 \mathrm{~kg} \mathrm{~S} \mathrm{ha}^{-1}$ and 180-230 kg N ha ${ }^{-1}$ achieved a corresponding 42-267\% increase in seed yield of Brassica napus L. However, application of the same rate $\left(180-230 \mathrm{~kg} \mathrm{~N} \mathrm{ha}^{-1}\right)$ without $\mathrm{S}$ diminished the seed yield significantly [85]. A study on Brassica compestris L. by Fazili et al. [90] revealed an increase in biomass accumulation with the combined application of $\mathrm{S}$ and $\mathrm{N}$. Combined application of $\mathrm{N}$ and $\mathrm{S}$ significantly improved leaf area index (LAI), leaf area duration, and leaf photosynthetic rate as compared to the control. This resulted in higher response magnitude in biological yield, seed yield, and enhanced oil yield of 98\%, 193\%, and $251 \%$, respectively [90]. 
Tiwari and Gupta [9] had earlier on discovered that $\mathrm{S}$ and $\mathrm{N}$ application significantly increased the grain yield of mustard (Brassica juncea L.). The increasing levels of applied S concomitantly increased $\mathrm{N}$ content and significant interaction occurred between $\mathrm{N}$ and $\mathrm{S}$ in influencing $\mathrm{N}$ concentration in plant tissues. Further, there was a significant positive interaction between applied $\mathrm{N}$ and $\mathrm{S}$ for $\mathrm{S}$ accumulation in the plant. The increase in concentration of $\mathrm{N}$ and $\mathrm{S}$ in the mustard plants was high when these nutrients were applied together than when applied individually [9]. Jamal et al. [87] working on soybean showed that $\mathrm{S}$ availability, just like $\mathrm{N}$, has a role in regulating nitrate reductase, in addition to its role in regulating ATPS. Besides, naturally occurring thiol compounds Cys and GSH were shown to influence nitrate reductase activity in wheat and Brassica [86].

The results by Salvagiotti et al. [91] showed an evident $\mathrm{S} \times \mathrm{N}$ synergism since the addition of $\mathrm{S}$ boosted $\mathrm{N}$ uptake as $\mathrm{N}$ fertilizer rates increased. $\mathrm{S}$ fertilization increased grain yield and $\mathrm{N}$ uptake by $7 \%$ and $22 \%$ respectively in the experiments conducted in farmer fields; and the increase in grain yield in response to $S$ addition was associated with a higher $\mathrm{N}$ uptake rate before anthesis. The work by Jamal et al. [88] in groundnuts has revealed that $\mathrm{S}$ is specifically involved in $\mathrm{N}$ fixation in legumes and $\mathrm{S}$ additions significantly increased $\mathrm{N}_{2}$ fixation, nodule weight plant ${ }^{-1}$, nodule weight per unit weight of root and $\mathrm{N}_{2}$ fixation per unit weight nodule. Further, Hocking et al. [92] reported a decrease of 30\% in Cys and Met concentration in seeds of $\mathrm{S}$ deficient but $\mathrm{N}$ sufficient sunflower plants.

\subsection{Interaction of $S$ with Non-N Nutrients}

Besides nitrogen, $\mathrm{S}$ is known to interact with almost all other essential macronutrients and micronutrients, with these interactions tending to either enhance or reduce crop growth, yield and quality by influencing the nutrient uptake and utilization [49,95-98]. The interactive effects of $S$ and $P$ application on yield and quality of cluster bean (Cyamopsis tetrogonoloba L.) were previously confirmed [97]. The synergistic effect of S and P was reported on increasing the number of nodules per plant, the weight of nodules per plant, protein (by $34.69 \%$ ), as well as N, P, and S contents [97]. A study conducted in California (USA) illustrated positive S-P interaction effects on increased forage production and the resulting improved sheep performance due to improved yields and nutritive value of the forage [99]. Phosphorus alone did not increase lamb gain significantly, but S-P interaction greatly increased production [99].

However, Islam et al. [100] discovered that the type of interaction between $\mathrm{S}$ and $\mathrm{P}$ depends on initial soil fertility status, levels of nutrients applied, test crop and climatic conditions of the region during crop growth. For instance, S-P interaction was synergistic at one experiment station, but antagonistic at another farmer's field when $\mathrm{S}$ and $\mathrm{P}$ were applied at higher rates ( $40 \mathrm{~kg} \mathrm{ha}^{-1} \mathrm{~S}$ and $80 \mathrm{~kg} \mathrm{ha}^{-1}$ respectively) in chickpea (Cicer arietinum $\mathrm{L}$.) seed. Individual effects of $\mathrm{S}$ and $\mathrm{P}$ application were significant on both seed yield and biological yield, but their interaction was non-significant for both parameters. Effect of $S$ and $P$ interaction was synergistic at all $S$ and $P$ levels at BARI experiment station, and this resulted in micronutrients $\mathrm{Zn}, \mathrm{Cu}, \mathrm{Fe}$, and $\mathrm{Mn}$ uptake. Sole application of $\mathrm{P}(40$; $\left.80 \mathrm{~kg} \mathrm{ha}^{-1}\right)$ and S $\left(15 ; 30 \mathrm{~kg} \mathrm{ha}^{-1}\right)$ also resulted in $(34 \%$ and $35 \%)$ and $(12 \%$ and $14 \%)$ increases in seed yield over control, respectively [100]. However, at another site (farmer's field), no significant benefits were derived from P (40 and $\left.80 \mathrm{~kg} \mathrm{ha}^{-1}\right)$ and S (15 and $30 \mathrm{~kg} \mathrm{ha}^{-1}$ ) interaction, but the individual effects of these nutrients generated significant seed yield increases of $22 \%$ and $32 \%$, and $10 \%$ and $16 \%$ over control, respectively [100].

In a study on the interactive effects of N, P, K, S, boron (B), and zinc (Zn) on yield response and nutrient uptake in rice, Dash et al. [98] observed that the highest significant grain yield (of $7.67 \mathrm{t} \mathrm{ha}^{-1}$ ) was realized when the crop received all the nutrients $(\mathrm{N}, \mathrm{P}, \mathrm{K}, \mathrm{S}, \mathrm{B}$, and $\mathrm{Zn}$ ). Omission of individual nutrients, such as $\mathrm{S}, \mathrm{Zn}$, and B, from the fertilizer schedule significantly decreased grain yield by $25.1 \%, 2.3 \%$, and $14.4 \%$ over treatment 1 (T1) (N + P + $\mathrm{K}+\mathrm{S}+\mathrm{Zn}+\mathrm{B}$ ), respectively, during the first year of study. The extent of limiting nutrients was in the order $\mathrm{Zn}<\mathrm{B}<\mathrm{S}<\mathrm{Zn}+\mathrm{B}+\mathrm{S}$ during first year [98]. The integrated use of all nutrients in $\mathrm{T} 1$ recorded highest grain yield response (37.23 $\mathrm{kg}$ grain per $\mathrm{kg}$ of the fertilizer 
applied). However, yield was reduced by $8 \%$ in the absence of S, B, and $\mathrm{Zn}$. The joint application of all these elements significantly enhanced individual elements' accumulation and uptake. However, among these nutrients, the omission of B significantly impacted $\mathrm{N}$, $\mathrm{P}$, and $\mathrm{K}$ uptake compared to $\mathrm{S}$ and $\mathrm{Zn}$ omission [98].

Farhad et al. [11] highlighted that $S$ in combination with $\mathrm{K}$ had a positive significant effect on grain yield and yield attributes of soybean. The highest grain yield $\left(2.35 \mathrm{t} \mathrm{ha}^{-1}\right)$ was recorded in K2S2 $\left(40 \mathrm{~kg} \mathrm{~K} \mathrm{ha}^{-1}\right.$ and $\left.20 \mathrm{~kg} \mathrm{Sha}^{-1}\right)$ treatment as compared to the lowest $\left(1.33 \mathrm{tha}^{-1}\right)$ observed in KOS0 treatment or where the two nutrients were applied individually. The interactive effect of $\mathrm{K}$ and $\mathrm{S}$ also showed a significant increase in protein content (38.4-44.6\%) and oil content (18.54-21.48\%) as compared to control treatment. Where either $\mathrm{S}$ or K were solely applied, statistically insignificant variation in both parameters (protein content and oil content) was observed.

Saha et al. [101] revealed the interactive effects of S, B and $\mathrm{Zn}$ on the yield and quality of groundnut (Arachis hypogea L.). Combined application of $30 \mathrm{~kg} \mathrm{~N} \mathrm{ha}^{-1}, 60 \mathrm{~kg} \mathrm{P} \mathrm{ha}^{-1}$, $30 \mathrm{~kg} \mathrm{~K} \mathrm{ha}^{-1}, 10 \mathrm{~kg} \mathrm{Zn} \mathrm{ha}{ }^{-1}$, and $50 \mathrm{~kg} \mathrm{~S} \mathrm{ha}^{-1}$ achieved a $73.4 \%$ nut yield increase compared to the control. Interestingly, results revealed that conjoint effect of $\mathrm{S}$ and $\mathrm{Zn}$ towards nut yield was more effective than that of $B$ application. The conjoint effect of $S$ and $\mathrm{Zn}$ also significantly increased their nutrient uptake in nuts. In addition, application of $\mathrm{S}$ and $\mathrm{Zn}$ significantly increased the oil content, while it significantly decreased the iodine value in groundnuts. It was then concluded that the interaction of these three nutrients in groundnuts would not only be effective in increasing yield and quality, but also their concentration and uptake without sacrificing yield [101].

In a study by Alam et al. [96], the $\mathrm{S} \times \mathrm{B}, \mathrm{S} \times \mathrm{Zn}$ and $\mathrm{B} \times \mathrm{Zn}$ gave negative interactions whilst NPK $\times S$ and NPK $\times$ B showed positive interaction on late jute seed yield in all the experiment locations. The combined effect of three factors $(\mathrm{S}, \mathrm{B}$, and $\mathrm{Zn})$ did not show the same trend of interactive effect in all the locations. However, the application of four factors (NPK, S, B, and Zn) gave significantly higher seed yield than the application of single, two, or three factors. In another study, positive interactions between $S$ levels and micro-nutrients iron $(\mathrm{Fe}), \mathrm{Zn}$, and manganese $(\mathrm{Mn})$ were observed on the yield and its components, chemical constituents, and storability of garlic [47]. There were significant interactions on total yield and bulb weight in both seasons and number of cloves/bulb and clove weight in the first season only. However, bulb weight was not significantly influenced in both seasons. Except for total soluble sugars, all the chemical constituents in cloves were considerably influenced by the S-Fe-Zn-Mn interactions in both seasons. Meanwhile, the $\mathrm{P} \%$ and $\mathrm{N} \%$ were only significantly affected in the first and second seasons, respectively. However, Zn concentration in the cloves showed no significant response to the interaction in both seasons. Positive interactions were also revealed on storability of bulbs, with the total weight loss \% during and at the end of the five-month storage period being realized from a higher rate of $S$ application with foliar spray of micronutrients at $250 \mathrm{ppm}$ [47].

Singh et al. [49] revealed that $S$ levels significantly increased the total N, P, S, and $\mathrm{Zn}$ uptake by biological produce (up to $60 \mathrm{~kg} \mathrm{~S} \mathrm{ha}^{-1}$ ) while a significant improvement in total $\mathrm{K}$ uptake due to $\mathrm{S}$ rate was recorded with up to $30 \mathrm{~kg} \mathrm{~S} \mathrm{ha}^{-1}$ in Brassica juncea. The increase in $\mathrm{N}$ uptake was thought to be due to an increase in $\mathrm{S}$ content resulting in the stimulation of protein synthesis and also due to its synergistic effect on the utilization of $\mathrm{N}$ by mustard plant.

Tiwari and Gupta [9] also revealed that $\mathrm{S}$ application improved $\mathrm{N}$ uptake $\left(\mathrm{kg} \mathrm{ha}^{-1}\right)$ ranging from $12.2 \%$ to $37.6 \%$ in wheat, $20.7-61.7 \%$ in hybrid rice, $37.0 \%$ in maize, $45.3 \%$ in mustard, $10.5 \%$ in linseed, and $44.3 \%$ in chickpea. Added S increased P uptake ( $\left.\mathrm{kg} \mathrm{ha}^{-1}\right)$ by $38.2 \%$ in mustard, $7.3 \%$ in linseed, $77.0 \%$ in rice, $52.7 \%$ in wheat, and $44.3 \%$ in maize. Likewise, $\mathrm{S}$ addition caused an increase in $\mathrm{K}$ uptake $\left(\mathrm{kg} \mathrm{ha}^{-1}\right)$ in maize, mustard, chickpea, hybrid rice, and wheat by $37.8 \%, 33.4 \%, 61.6 \%, 62.4 \%$, and $110.2 \%$, respectively. These examples clearly highlight the impact of $\mathrm{S}$ interactions with $\mathrm{N}$ and non-N nutrients, thereby directly influencing the uptake, assimilation, nutrient use efficiencies, and the ultimate yield and quality of various crops. 


\section{Sulphur Role in Stress Tolerance}

Sulphur plays an important role in physiology and protection of plants against environmental stresses and pests through its antioxidative protective functions [20,22,32,33]. Particularly, ATPS participates in plant abiotic stress tolerances via different S-containing compounds, especially GSH which acts as a storage and transport form of reduced-S [102]. Because of the high reactivity of thiol (-SH) groups, S-compounds, including Cys and GSH, are central for metabolic redox regulation [71]. Major induction of the GSH-based stress defense system, its role in ROS scavenging and cellular-redox homeostasis maintenance has been extensively proven in plants under different environmental stresses [102-104]. Sulphur role in ameliorating ROS induce oxidative stress in plant cells has been well documented in alleviation of salinity stress [18,32,33,65,105-107], metal induced oxidative stress [20,32], multiple abiotic stresses [22]. Since plants are often exposed to combinations of abiotic stresses, such as heat, light, cold, drought, salinity, and toxic metals, $\mathrm{S}$ can play a significant role in conferring resistance to these stresses.

Sulphur is the major modulator of GSH-mediated control of plant stress tolerance. It is incorporated into organic molecules and is located in thiol (-SH) groups in proteins (Cys/Cys-residues) or non-protein thiols (NPT; GSH), maintains homeostasis of GSH and oxidized GSH ratios, and protects plants from oxidative damage. Glutathione plays a multifaceted role in plant metabolism as plants can withstand cadmium toxicity by maintaining high levels of phytochelatins or its precursor, GSH, which functions as a metal ligand [20]. In a review of their earlier work, Mazid et al. [32] highlighted that, once plants are exposed to heavy metals such as cadmium, phytochelatins (y-Glu-Cys)n-Gly are synthesised from GHS, which consequently scavenges for ROS. In addition, heavy metal stress promotes the expression of $S$ assimilation and transporter genes. Besides being a key structural constituent of proteins, Cys functions as a metabolic $\mathrm{S}^{2-}$ donor for the essential biomolecules such as GSH (thiols) and several secondary $\mathrm{S}$ defense metabolites, including glucosinolates, allins, thionins, or phytochelatins [22]. Meanwhile, biosynthesis of GSH is dependent on the availability and cross-talking with its constituent amino acids Cys, glutamic acid, and glycine. The cross-talk is attained in two ATP-dependent steps, facilitated by separate enzymes c-glutamylcysteine synthetase and GHS synthetase [72,108].

Plants can metabolically acclimatize to joint attack of salinity and metal stresses, by enhancing their synthesis of S-rich peptides, particularly GSH and amino acid (osmolyte) proline [109-111]. Sulphur forms the thiol groups of GSH and thioredoxin, which are directly responsible for the modulation of intracellular redox state [112]. GHS plays its protective role against oxidative and environmental stress by depressing or scavenging the formation of toxic ROS such as superoxide and lipid hydro peroxides. It therefore serves as a thiol buffer in the protection of proteins via direct reaction with ROS or by the formation of mixed disulphides. Thus, the redox properties of $S$ element in proteins, and of S-containing metabolites, are particularly important in the interaction between the reductive assimilation processes of photosynthesis and ROS that arise as by-products of electron transport chains [22]. Increased S metabolism and production of S metabolites are of paramount importance in maintaining redox state of the cell as a response against increasing salinity induced oxidative stress [65]. Sulphur metabolites also enhance tolerance by modulating physiological and molecular processes and by up-regulating genes for stress tolerance [105]. These macromolecules provide structural or redox balance in proteins, via $\mathrm{S}$ donation in Fe-S clusters, vitamin biosynthesis, or ROS and xenobiotics detoxification $[65,103]$. Besides these roles, $S$ application has also been reported to improve photosynthetic efficiency and growth in barley plants under salinity [105].

Studies have also shown that $S$ supply protects plants from adverse effects of salinity in barley [113] and mustard [106] by increasing GSH content. Meanwhile, Atcys-3A gene coding for OASTL isoform, and abundantly localized in the cytosol has been observed to actively participate in Arabidopsis' salinity defense response [114]. Higher Cys synthesis in the plants supports the efficiency of the thiol-metabolism based salinity tolerance [115]. Moreover, the over-expression of cysteine synthase (CSase) and serine acetyltransferase 
(SAT), key enzymes of Cys biosynthesis, was related to higher tolerance to oxidative stress and the overexpression of these enzymes is a promising tool for engineering $S$ assimilation for higher Cys and GHS synthesis [65,112]. A positive correlation has been shown between the $S$ content in the soil and antioxidant activity in onions [107]. The results of $S$ fertilization at $14.6 \mathrm{mg} \mathrm{S} \mathrm{kg}^{-1}$ soil were statistically significant over control. In addition to increased content of polyphenols in onion, a positive correlation between the content of the total polyphenols and antioxidant activity was evident, thus confirming $S$ role in oxidative stress tolerance.

Sulphur assimilation rate and biosynthesis of GHS were greatly increased in Brassica napus plant exposed to saline conditions [116]. Salinity regulates key enzyme of $\mathrm{SO}_{4}{ }^{2-}$ assimilation, APR activity under salinity stress. Moreover, the increase in APR activity could be found to be correlated with a higher rate of Cys synthesis to adjust the increased demand for GSH. Furthermore, GSH confers multiple roles abiotic stress defenses in plants through different ways; first, by reducing the ascorbate in ascorbate-glutathione cycle. Secondly, GSH accumulation is found to compensate for decrease in the capacity of other antioxidants, for example, in catalase-deficient mutants and in plants where catalase activity has been reduced by antisense technology. Thirdly, when GSH is depleted, increased sensitivity to oxidative stress has frequently been found, and in instances where GSH depletion has not increased sensitivity to oxidative stress, it is probable that other antioxidant molecules are increased to compensate for decreases in GSH [32]. GSH peroxidases are also induced in plants in response to abiotic stress. These enzymes are involved in detoxification of lipid peroxidases and the efficient recycling of GSH is ensured by glutathione reductase (GR) activity [17]. The components of this cycle exist in both chloroplast and cytosol and evidence for their presence in mitochondria, glyoxysome and peroxisome has also been reported [33]. However, there still exist many gaps in our knowledge regarding the biosynthesis of $S$ assimilatory metabolites and their defense responses to oxidative and heavy metal stress conditions in higher plants as well as in the soil-plant system. Therefore, it is crucial to explore further the significance of these metabolites in the mechanisms of tolerance against oxidative stress.

Besides conferring plant abiotic stress resistance, $\mathrm{S}$ provides vital roles in plant protection against pest and pathogenic stresses in certain species through what is known as "sulphur-induced defense" [37,41]. Some plant species possess secondary S compounds, such as glucosinolates in Brassicas [117], alliins and $\gamma$-glutamyl peptides in Allium [118], S-rich proteins (thionins), and phytoalexins, which may offer resistance against herbivory and pathogen attack [36]. It has been shown that a lack of these secondary S compounds weakens the plant pathogen defense capabilities [41]. Upon plant tissue disruption, glucosinolates are degraded by the myrosinase enzyme to produce diverse bioactive products, including thiocyanates, isothiocyanates, and nitriles. The ensuing glucosinolate-myrosinase complex is presumed to play a role in plant-pest and plant-pathogen interactions, probably through release of volatile, toxic, or pest repellent compounds [36]. In Allium species, the synthesized alliins (catalyzed by the enzyme alliinase) and $\gamma$-glutamyl peptides are thought to provide chemical defense, also via the production of volatile S-containing compounds [119], including $\mathrm{H}_{2} \mathrm{~S}[17,117,120]$. For an extensive review on the role of sulphur in plant pathogenic stress resistance, we refer you to Zhao et al. [36]. Noticeably, the concept of 'sulphur-induced defense' is yet to be fully understood. Hence, this is a potential avenue for further exploration.

\section{Sulphur and Crop Production}

\subsection{Sulphur Requirements of Crops}

Plant species vary largely in their $S$ requirements. Adequate and balanced $S$ nutrition is crucial for their production, quality, and health $[34,36,69,121]$. The $S$ requirement by plants varies with the developmental stage and with species whereas its concentration in plants varies between $0.1 \%$ and $1.5 \%$ of dry weight [20]. Even in its lesser (3-5\%) abundance in relation to $\mathrm{N}$, plant $\mathrm{S}$ fulfills central roles in numerous metabolic pathways. $\mathrm{S}$ removal by 
an average crop under subsistence agriculture is $3-4 \mathrm{~kg}$ in cereals, $5-8 \mathrm{~kg}$ in sorghum and millets, $8-12 \mathrm{~kg}$ in pulses, and more than $12 \mathrm{~kg}$ in oilseeds. The $S$ requirements of crops in comparison to $\mathrm{P}$ is generally in the ratio (P: $\mathrm{S}$ ) of 1.3 for cereals, 0.8 for legume forages, and 0.6 for crucifers. Apparently, in oilseeds, $S$ uptake is almost twice that of $P$ uptake [9]. By specie type, Brassicas such as oil rapeseed and mustard possess superior $S$ needs as compared to Graminaceous species, and hence, Brassicas are more sensitive to $S$ deprivation than cereal crops [34]. For example, the production of 1 tonne $(t)$ of rapeseed requires $16 \mathrm{~kg}$ of $\mathrm{S}$ compared to $2-3 \mathrm{~kg}$ for each tonne of grain in wheat [20]. Consequently, crop plants have been generally categorized into three classes based on their $\mathrm{S}$ requirements, i.e., high (oil rapeseed, mustard, Cruciferous vegetables, alfalfa, etc.), medium (cotton, grasses, sugarcane, coffee, etc.), and low (cereals, groundnut, sugar beet, etc.) $\mathrm{S}$ requiring species [34,43].

\subsection{Yield and Quality Effects of S in Different Cultivated Crop Species}

The growth, yield, and quality effects of $S$ in different crop species have been revealed in several previous studies, most of which have already been hinted in Section 5 above, when we were highlighting the interactive effects of $S$ with other nutrients. Here, we shall discuss some few examples further. Thus, $\mathrm{S}$ has shown positive effects on growth, yield and quality in sunflower [12,93], winter wheat [10], soybean [11,121], maize [8,13,122-124], spinach and pepper [48], onion [14,15], mustard [49], canola oil rapeseed [44], several crops [125], grasslands [126], and green mealies (Zea mays L. var. ceratina, rugosa and saccharata) [127] among others.

Rasool et al. [12] observed increases in growth parameters, yield characters, seed yield, oil content and yield with high applications of $S$ fertilizer in sunflower. Application of $\mathrm{S}$ at $60 \mathrm{~kg} \mathrm{ha}^{-1}$ recorded $2.3 \%, 23.5 \%$, and $12 \%$ increases in plant height, LAI, and dry matter production, respectively, over $30 \mathrm{~kg} \mathrm{~S} \mathrm{ha}^{-1}$. This was attributed to $\mathrm{S}$ regulating the metabolic and enzymatic processes including photosynthesis and respiration. Yield characters were significantly influenced by $S$ application of $60 \mathrm{~kg} \mathrm{~S} \mathrm{ha}^{-1}$ over $30 \mathrm{~kg} \mathrm{~S} \mathrm{ha}^{-1}$. Seed yield increased significantly with higher $S$ application, probably due to better partitioning of photosynthate to the reproductive parts of the plants being influenced by higher rates of S. As compared to $30 \mathrm{~kg} \mathrm{~S} \mathrm{ha}^{-1}$ rate, $60 \mathrm{~kg} \mathrm{~S} \mathrm{ha}^{-1}$ offered a $2 \%$ and $10.55 \%$ increase in oil content and yield, respectively [12].

Jarvan et al. [10] working on winter wheat revealed $S$ fertilization $\left(10 \mathrm{~kg} \mathrm{~S} \mathrm{ha}^{-1}\right)$ on $\mathrm{N}$ background (100 $\mathrm{kg} \mathrm{N}^{-1}$ ) increased the winter wheat grain yield, depending on weather and soil conditions, between 7.7-45.5\%. Sulphur fertilization reduced the wet gluten content but improved the overall biological value of proteins. Although the protein quality was low (as determined by proportion of glutenins in gluten), the total Cys and Met contents of the wheat grains was increased [10]. Thus, the effect of $S$ on the protein and wet gluten contents of wheat grain was not always unidirectional, but in all trials, the gluten index increased, and the quality of protein improved under influence of $S$. The content of S-containing amino acids was also increased, Cys, Met, threonine, and lysine were increased by $24.5 \%, 35.5 \%, 14.4 \%$, and $7.7 \%$ respectively [10].

A recent study by Tao et al. [128] discovered that $S$ fertilization at $45 \mathrm{~kg} \mathrm{~S} \mathrm{ha}^{-1}$, $200 \mathrm{~kg} \mathrm{~N} \mathrm{ha}^{-1}, 183 \mathrm{~kg} \mathrm{P} \mathrm{ha}^{-1}$, and $163 \mathrm{~kg} \mathrm{~K} \mathrm{ha}^{-1}$ significantly $(p<0.05)$ increased wheat grain yield and grain weight in both (GY2018 and ZM8) cultivars. On average (of both years), wheat yield and grain weight increased by $34.7 \%$ and $30.2 \%$ compared to the control (no S applied) in GY2018, whilst the increases were $11.2 \%$ and $14.2 \%$ higher in ZM8 than the control. Additionally, S significantly $(p<0.05)$ improved grain protein content and protein yield in both cultivars. Compared to control, $45 \mathrm{~kg} \mathrm{~S} \mathrm{ha}^{-1}$ treatment increased protein content by $16.6 \%$ in GY2018, and 6.2\% in ZM8, on average for both years [128].

Moreover, $\mathrm{S}$ fertilization had significant effect on yield, yield attributes and protein content of soybean. Application of $S$ at $20 \mathrm{~kg} \mathrm{ha}^{-1}$ in soybean produced the highest plant height, seed yield (1000-seed weight) and straw yields as compared to the lowest responses realised from the control treatment [11]. Different doses of S showed significant variations 
in respect of both straw yield and grain yield, with $20 \mathrm{~kg} \mathrm{~S} \mathrm{ha}^{-1}$ showing the highest yields of $1.95 \mathrm{t} \mathrm{ha}^{-1}$ and $2.08 \mathrm{tha}^{-1}$ respectively, against the lowest yields of $1.52 \mathrm{t} \mathrm{ha}^{-1}$ and $1.61 \mathrm{t} \mathrm{ha}^{-1}$ respectively realized in no $S$ treatment [11]. Additionally, $\mathrm{S}$ had significant effects on harvest index value, cob length and number of grains per row in maize as all these parameters increased with increasing $S$ and $N$ values [13]. The increase in the number of grains per row in the case of increasing $S$ and $N$ levels was mainly attributed to greater cob length. In another report, Xie et al. [8] showed that the grain quality of maize was not only affected by N, but also by S. The contents of the proteins, amino acids, and soluble sugar increased by $1.87 \%, 2.64 \%$, and $1.27 \%$, respectively, in variety 1 (LY16) compared to control. However, $\mathrm{S}$ did not result in obvious increase in crude fat content, oil content, and micro elements except in combination with $\mathrm{N}$.

In another study, the addition of $150 \mathrm{~kg} \mathrm{~N} \mathrm{ha}^{-1}$ and $30 \mathrm{~kg} \mathrm{~S} \mathrm{ha}^{-1}$ fertilizers at 5:1 $\mathrm{N}$ : $\mathrm{S}$ ratio yielded the highest returns by influencing plant height, dry matter production, kernels per row, kernels per cob and kernel weight per ear [123]. Further, Jeet et al. [124] revealed that the application of $150 \mathrm{~kg} \mathrm{~N} \mathrm{ha}^{-1}$ and $45 \mathrm{~kg} \mathrm{Sha}^{-1}$ significantly enhanced the yield, quality, and profitability of quality protein maize.

In their study, Singh and co-workers realized that increasing $S$ levels up to $60 \mathrm{~kg} \mathrm{ha}^{-1}$ significantly enhanced yield in Brassica juncea [49]. Increasing S level up to $60 \mathrm{~kg} \mathrm{~S}^{-1}$ significantly enhanced siliqua/plant, and seeds/siliqua. However, test weight improved significantly up to $30 \mathrm{~kg} \mathrm{Sha}^{-1}$. Percent increase in seed yield due to $\mathrm{S}$ application was 15.5 and 19.7 for $30 \mathrm{~kg} \mathrm{~S} \mathrm{ha}^{-1}$ and $60 \mathrm{~kg} \mathrm{~S} \mathrm{ha}^{-1}$ over control, respectively. The authors also revealed that the pronounced effect of $S$ application on LAI was probably due to $S$ enhancing the photosynthetic activity of the plants [49]. Malavolta et al. [125], testing the response of several tropical crops (beans, cabbage, citrus, maize, coffee, rapeseed, Guinea grass, upland rice, soybean, sweet sorghum, sugarcane, and wheat) to $S$, realized yield increases of $8-69 \%$ over the control. S additions also had beneficial effect on product characteristics, viz., grain/cob ratio in maize, crude protein in forage, oil content of soybean, and sucrose content of sweet sorghum.

However, the work by Hassan et al. [44] on canola oil rapeseed showed that $\mathrm{S}$ effects on seed yield, oil protein and glucosinolates were neither significant nor consistent. Although cultivar $\times \mathrm{S}$ interactive effects and the cultivar $\times \mathrm{S} \times$ year interactive effects were statistically significant, the response of $S$ on seed yield was non-significant, suggesting that the yield of canola oil rapeseed increases on severe $S$ deficiency soils. S levels did not show any impact on glucosinolate accumulation, and neither did they exhibit any impact on protein accumulation. However, $\mathrm{S}$ impact between years was found to be significant. The seasonal differences in $S$ response of the crop were thought to be the result of seasonal dryness particularly during reproductive phase [44].

In our previous study, we observed that $S$ significantly enhanced both yield and quality in green mealies [127]. At $195 \mathrm{~kg} \mathrm{~N} \mathrm{ha}^{-1}, 150 \mathrm{~kg} \mathrm{P} \mathrm{ha}^{-1}, 105 \mathrm{~kg} \mathrm{~K} \mathrm{ha}^{-1}$, and $38 \mathrm{~kg} \mathrm{~S} \mathrm{ha}^{-1}$, total fresh ear yield ha ${ }^{-1}$ was significantly increased by $18.12 \%, 17.53 \%$, and $6.58 \%$ in TDN21, JKN2000, and JKN928 cultivars, respectively, compared to control (no S applied). This was as a result of $S$ positively influencing some yield components. Additionally, $S$ substantially improved the kernel taste by increasing relative sweetness and flavour in all three cultivars. Moreover, S significantly increased crude protein in TDN21, and crude starch by $4.31 \%$ and $7.56 \%$ in TDN21 and JKN2000, respectively. Further, S enhanced harvested ears external appearance in TDN21 and JKN2000 cultivars, contributing to quality improvement [127].

\subsection{Sulphur Deficiency Symptoms and Diagnosis Approaches}

Since $S$ is an essential constituent of proteins, its deficiency leads to low level of $S$ containing amino acids in plants and thus depresses protein synthesis [77]. For this reason, non-S containing amino acids amide and nitrate can accumulate in $\mathrm{S}$ deficient plants. The accumulation of amide $\mathrm{N}$ is associated with low levels of sugars resulting from poor photosynthetic activity of $S$ deficient chlorotic plants. The ratio of 'organic N: organic $S^{\prime}$ 
is considerably higher in S deficient plant tissues compared with normal plant tissues [9]. When crop plants are deprived of S, they may show visual symptoms of S deficiency; with the classical symptom being yellowing of younger leaves while older leaves remain green. Plants deficient in $S$ are generally small, spindly with slender stalks and they often mature late [23]. For detailed reviews on deficiency symptoms in different crop species, we refer you to previous articles $[9,129]$. Some of the visual symptoms of $S$ deficiency in selected crop species are shown in Figure 3.

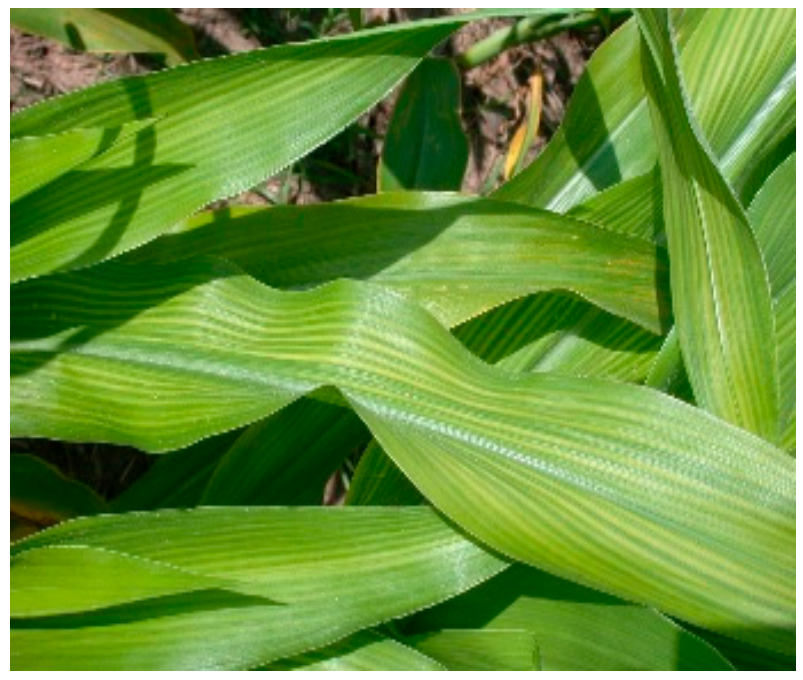

(a)

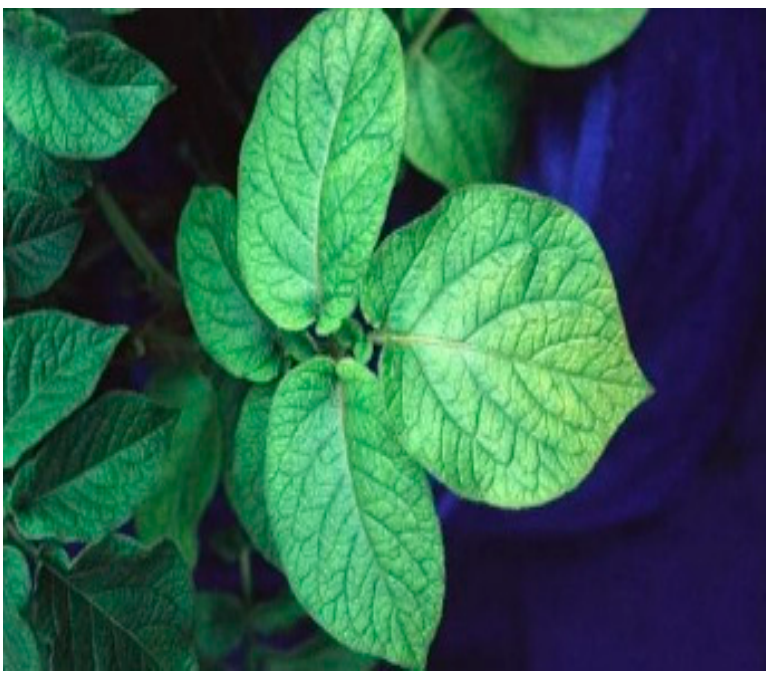

(b)

Figure 3. Visual symptoms of sulphur (S) deficiency in selected crop species: (a) Maize. S deficiency exhibits itself as interveinal chlorosis; (b) Soybean. Plants show pale yellow colour of new leaves at the beginning and gradually the whole plant turns yellow due to severe S deficiency, plants have smaller leaves and shorter internodes. Photo credits: Both photographs shown here are used with permission from Smart Fertilizer UK (https:/ /www.smart-fertilizer.com/ accessed on 15 September 2020) and due credit is therefore hereby accorded. The photographs were sourced from their website: https:/ / www.smart-fertilizer.com/articles/sulfur/ (accessed on 15 September 2020).

Symptoms of $\mathrm{S}$ deficiency occur particularly in plants well supplied with $\mathrm{N}$ but are sometimes confused with that of $\mathrm{N}$ [83]. In this instance, leaf analysis can be invaluable. Previously, in studies seeking to address what was perceived as specific nutrient deficiencies, researchers were applying fertilizers such as ammonium sulphate $\left(\left(\mathrm{NH}_{4}\right)_{2}\right.$ $\left.\mathrm{SO}_{4}\right)$, potassium sulphate $\left(\mathrm{K}_{2} \mathrm{SO}_{4}\right)$, zinc sulphate $\left(\mathrm{ZnSO}_{4}\right)$, and superphosphate, and the responses attributed to $\mathrm{N}, \mathrm{P}, \mathrm{K}$, and $\mathrm{Zn}$ may have been partially emanating from $\mathrm{S}$, or its interactions with other nutrients [34]. In this regard, any such unobserved nutrient interactions calls for the need to accurately detect deficiencies and provide plants with a balanced supply of nutrients.

However, determining $\mathrm{S}$ tissue content and requirement remains a challenge in crop production. Meanwhile, good agricultural practice in fertilizer use demands the evaluation of the $S$ status of crops as a measure for determining the required amount of $S$ fertilizer. Basically, there are three main $S$ diagnosis approaches, viz., visual assessment, tissue analysis, and soil analysis. Visual detection can be used as a practical and quick diagnostic tool, involving the assessment of $S$ deficiency by the naked eye. Visual diagnosis on single plants requires specific deficiency symptoms, which are easily identifiable in dicotyledonous than in graminaceous plants. Particularly because of distinctive symptoms on leaves, flowers, and yield structure, the visual identification of $S$ deficiency in Brassica species is fairly straightforward [130]. However, in cereal crops, visual detection tends to be difficult, since in young plants it may be confused with N deficiency [34,83]. Generally, an irregular appearance of the whole field may give hints. Deficiency symptoms in cereals, 
grasses, and brassicas show up in the younger leaves first, as a pale-yellow appearance (chlorosis) and later stunting [83].

A major limit of visual diagnosis of nutrient disorders is that usually only situations of severe deficiency can be detected, with the identification of moderate or sub-clinical (hidden) deficiency seeming only possible by chemical analysis. This 'hidden' deficiency may be exhibited by abnormal changes in the yield structure. However, to be verified, it requires an estimation and evaluation of the plant tissue $S$ concentration [130]. It is important to note that plant families and species exhibit great diversity in their $\mathrm{S}$ concentrations. As already highlighted, graminaceous species have lower $\mathrm{S}$ levels than dicotyledonous species $[20,34,43]$. Remarkably, within each genus, those species possessing $\mathbf{S}$ containing compounds (secondary metabolites) accumulate more $S$ than those without. Thus, higher $S$ accumulating plant species, such as the Brassica species, are very suitable as monitor crops to evaluate differences between sites and environments or for quick growing tests [130]. Since plants change their appearance continuously during their growth cycle, in response to added nutrition amendments and method used, and depending on the age of the plant, conducting plant tissue analysis will require that the samples be organ-specific and for defined crop growth stages [34]. Total $S$ is the most suitable parameter to evaluate the $S$ status of plants, although it needs higher analytical effort. Additionally, although it is more dependent on short term physiological variations, the determination of $\mathrm{SO}_{4}{ }^{2-}$ by quick tests may be useful in the field for a rough evaluation of the $S$ status [130]. However, if used for fertilizer recommendation, the time factor delay is one of the major setbacks of plant tissue analysis. Further, although there are now test systems available which allow for the determination of total plant $\mathrm{S}$ with some spectral imaging equipment, most of this equipment is currently highly priced.

On field locations experiencing little to no lateral or vertical water movements, soil analysis can be a viable option for performing $S$ status diagnosis [51]. However, on sites with high physical mobility and losses of $S$, soil analysis will not accurately evaluate the $S$ nutritional status. In such cases, a site assessment which takes into account the physical $\mathrm{S}$ mobility and $\mathrm{S}$ loss factors offers better results than chemical soil analysis [130]. Care must also be taken when collecting soil samples because the results could be biased due to previous treatments, such as burning of crop residues and animal grazing habits and management [43].

\subsection{Crop S Sources and Supply (Fertilizer) Recommendations}

A broad assortment of S-containing materials is available for use as fertilizers; with some containing soluble $\mathrm{SO}_{4}{ }^{2-}$ that provides immediately plant available $\mathrm{S}$, and others that contain insoluble $\mathrm{S}^{0}$ that requires oxidation to $\mathrm{SO}_{4}{ }^{2-}$ before the plant can access the additional nutrients [131]. Sulphur sources, such as gypsum, elemental S, pyrite, and sulphuric acid, have been in use as fertilizers. Compounds such as $\mathrm{K}_{2} \mathrm{SO}_{4}$, ammonium sulphate (AS), single super phosphate (SSP) and magnesium sulphate $\left(\mathrm{MgSO}_{4}\right)$ have also been used as $\mathrm{S}$ supplying fertilizers $[34,43]$. These $\mathrm{S}$ containing materials supply $\mathrm{S}$ in $\mathrm{SO}_{4}{ }^{2-}$ form which is immediately available for plant uptake (www.sulphurinstitute.org/ about-sulphur/ accessed on 22 March 2020). Easily soluble S containing materials, viz., $\mathrm{K}_{2} \mathrm{SO}_{4}$, AS, SSP, and $\mathrm{MgSO}_{4}$, are considered suitable in neutral to slightly alkaline soils since plants take up $\mathrm{S}$ in $\mathrm{SO}_{4}{ }^{2-}$ form. Further, in those crops that need to be fertilized with $\mathrm{S}$ and $\mathrm{P}$, the preferred source will be SSP instead of other $\mathrm{P}$ sources such as diammonium phosphate [43].

Modern technologies have improved the direct application of $S^{0}$ based fertilizers as the most concentrated $\mathrm{S}$ carriers, or as additives to NPK fertilizers. Examples of $\mathrm{S}^{0}$ based fertilizers include $\mathrm{S}$ bentonite, $\mathrm{S}^{0}$ fortified N/P fertilizers and $\mathrm{S}$ coated fertilizers (http: / /irasulph.com/different-types-sulphur-bentonite-fertilizer/ accessed on 22 March 2020). Sulphur can also be supplied in liquid forms, such as ammonium thiosulphate, potassium thiosulphate and calcium thiosulphate. However, low water solubility hampers the use of several S liquid formulations (www.sulphurinstitute.org/about-sulphur/ accessed on 
22 March 2020). Meanwhile, SOM and animal manures can provide S along with other plant nutrients. However, the solid organic materials are slow release and their $\mathrm{S}$ content and balance with other nutrients is variable and should be determined through manure analysis along with soil testing to determine relative requirements. For example, some liquid pig manures have low contents of available $S$ relative to $N$, and crop responses to supplemental $\mathrm{S}$ fertilizer have been observed on manure added soils in field trials where $\mathrm{S}$ deficiencies exist [131,132].

As already highlighted in this discussion, crop species vary greatly in their $\mathrm{S}$ requirements. Generally, the higher the $\mathrm{S}$ demand, the higher the sensitivity to deficiency. Oil rapeseed has a very high $S$ uptake compared to other crops species, but most of its $S$ remains in plant residues [81]. Several researches have provided recommended optimum rates of $S$ application to different crop species as shown in Table 2.

Table 2. Recommended optimum S application rates in selected crop species.

\begin{tabular}{ccc}
\hline Crop Species & Optimum S Rate $\mathbf{( k g ~ h a - 1 )}$ & References \\
\hline Cereals & $24-40$ & {$[43,133]$} \\
Cereals & $25-50$ & {$[83]$} \\
Cereals & $30-40$ & {$[9]$} \\
Winter cereals & $40-50$ & {$[81]$} \\
Spring cereals & $20-25$ & {$[81]$} \\
Oilseeds & $10-150$ & {$[43,133]$} \\
Oilseeds & $30-60$ & {$[9]$} \\
Oil rapeseed & $50-75$ & {$[83]$} \\
Oil rapeseed & $75-100$ & {$[81]$} \\
Oil rape seed & $>58.3$ & {$[34]$} \\
Pulses & $20-40$ & {$[43,133]$} \\
Pulses & $30-45$ & {$[9]$} \\
Peas & 25 & {$[83]$} \\
Fodder & $25-100$ & {$[43,133]$} \\
Fodder & $40-60$ & {$[9]$} \\
Grass for silage & 40 & {$[83]$} \\
Grassland -silage & 40 & {$[81]$} \\
Grass for grazing & $20-30 /$ cut & {$[83]$} \\
Grassland -grazing & $10 /$ month & {$[81]$} \\
Tubers & $25-60$ & {$[43,133]$} \\
Potato & $40-80$ & {$[9]$} \\
Onion and garlic & $40-50$ & {$[9]$} \\
\hline
\end{tabular}

\section{A View into the Future}

For the past two decades, significant progress has been achieved in $\mathrm{S}$ research aimed at explaining the role of $S$ in increasing yields and improving the nutritional quality of crops, $S$ uptake and metabolism, and identification of $S$ nitrate transporter genes, identifying the role of $\mathrm{S}$ macronutrient in abiotic and biotic stress responses, and formulating recommended $\mathrm{S}$ application rates for different crop species. However, significant gaps in our knowledge related to most of these aspects of $S$ nutrition remain. Some of the priority areas for further research are hereafter discussed.

Given the importance of $S$ geochemical cycle in the environment, the processes and dynamics of $S$ transformation between the atmospheric, plant, and soil systems needs to be explored further [7]. This is particularly relevant in order to understand the relationship of $\mathrm{S}$ element with other gases (greenhouse gases) within the atmosphere. Additionally, going forward, the interactions between the plants and rhizospherical microbes, particularly rhizobia and arbuscular mycorrhizal fungi, should be investigated in order to establish the symbiotic relationships between plants and these microbes, with regards to $S$ mineralization and $\mathrm{N}$ fixation. The role of $\mathrm{S}$ metabolites in aiding mutualistic interactions between plants and rhizospherical microbes still needs to be explored [134]. 
Further, investigations on the interactions between $S$ and other plant nutrients need to be advanced to establish the exact $S$ contributions (synergistic or antagonistic) to other nutrients uptake and metabolism by plants. This is so relevant considering that $\mathrm{S}$ deficiency or over supply may result in toxicity or fixation of other essential nutrients. This therefore calls for appropriate soil nutrient balancing for specific cropping patterns, that is, in terms of correct rates and proper timing for application as well as accounting for residual $\mathrm{S}$ amounts in the soil and plant residues.

Plant biology studies aimed at providing further insights into the molecular mechanisms underlying plants response and tolerance to deficient or excess $\mathrm{S}$ conditions should exploit the use of next generation sequencing technologies and omics approaches to strengthen the analysis of transcriptome, proteome, post translational modifications, and metabolomes of plants exposed to deficient or excess $\mathrm{S}$ conditions, respectively. Key genes, proteins, and metabolic networks regulating $S$ perception, signalling, uptake, utilization, and nutrient crosstalk, will need detailed characterization and the promising ones deployed for transgenic breeding of high SUE plants. Moreover, precise and detailed functions of S containing metabolites on effecting plants' molecular response and tolerance to specific environmental and pathogenic stresses need to be dissected.

Another topical issue relating to $S$ nutrition is animal nutrition and performance. Whereas plants and microbes are able to utilize inorganic $\mathrm{S}$ and $\mathrm{N}$ sources to synthesize S-containing amino acids, several enzymes and vitamins, higher animals (especially nonruminants) rely on plants or preying their predators to meet their needs for energy and essential amino acids [34]. Thus, we must underline that $\mathrm{S}$ is critical in enhancing the nutritive (protein) value of grasses or silage for animal grazing or feeding, respectively [83]. Notwithstanding the fact that crop fertilization can change the N:S ratio by altering the proportion of amino acids, proteins, and other S-containing constituents in the plants, fertilizing fodder crop does not always translate to automatically enhanced animal performance. Whereas moderate $S$ fertilization is essential to overcome plant $S$ deficiencies, large $S$ application rates are often needed to increase protein levels, but may also lead to leaching losses or toxicity in animal systems. Therefore, detailed research by both agronomists and animal nutritionists is required to ascertain the actual merits of forage fertilization versus feed supplementation with regard to the efficient provision of ruminants' $S$ requirements [34].

Precision phenotyping of crop plants for $S$ deficiency or toxicities cannot be over emphasized. Researchers can make use of recent advances in high throughput plant phenotyping technologies to perform image-based plant nutrition analysis (PNA). For instance, imaging technologies currently being deployed in PNA include spectroscopy imaging, fluorescence imaging, and red-green-blue (RGB) imaging. Such image-based PNA is non-destructive and revolves around understanding the connections between plant nutrient concentrations and phenotypic changes related to the colour, texture and light reflectance ratio of the foliage [135]. Therefore, looking into the future, we can leverage the availability of these new tools to precisely dissect plant $S$ contents and establish accurate $S$ requirements of individual specific crop species. This will offer us a perfect guide regarding the rates of $S$ and non-S fertilizers to apply for optimum, resource use efficient, and sustainable crop production. Last but not least, $\mathrm{S}$ nutrition and its effect on the quality (with regards to protein and oil contents and other taste parameters) of harvested products should be precisely analyzed. The aspects related to the future of $S$ research are summarized in Figure 4. 


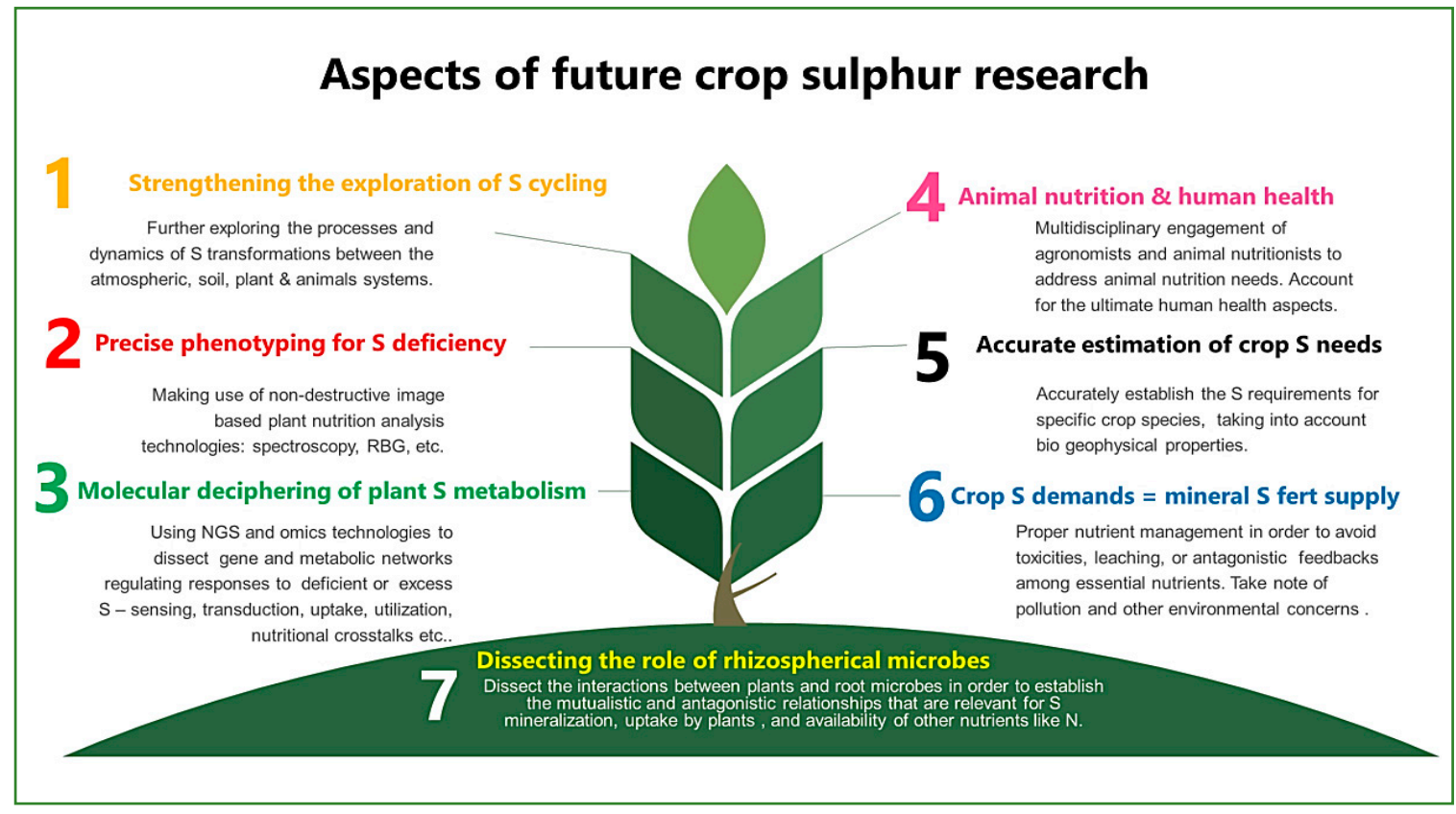

Figure 4. Schematic representation of the key aspects of future crop sulphur research. An integrated multi-disciplinary approach will be needed in $S$ research areas, including accurate plant tissue $S$ estimation, precision phenotyping for nutrients deficiencies, molecular dissection of plant $S$ metabolism, meeting crop $S$ needs, addressing animal nutrition requirements and human quality diet complexities. Note: S, sulphur; NGS, next generation sequencing; RBG, red-blue-green imaging technology.

\section{Conclusions}

Sulphur plays key roles in the primary metabolism of plants, conferring antioxidative and protective physiological functions against numerous abiotic stresses. In our quest to meet the rising food, animal feed, and biofuel demands for the surging human population, $S$ may play a central role, just like other macronutrients, in sustainable soil fertility management, improving crop productivity and enhancing the production of high nutritive-value crops. Therefore, as we move into the future, we need to revive our focus on sulphur nutrient. Greater efforts should revolve around bettering our understanding of the molecular processes and dynamics of $S$ availability and utilization in plants, deciphering the dynamics of $S$ interactions with other nutrients, exploring the role of soil rhizospherical microbes in plant $S$ transformations, enhancing plant phenotyping and diagnosis for nutrient deficiencies, precise estimation of crop $S$ requirements for optimum production, and matching site-specific crop $S$ demands with fertilizer amendments in order to reduce $S$ use inefficiencies in both crop and livestock production systems. This will facilitate the proper utilization of sulphur in crop production and eventually enhance sustainable and environmentally friend food production.

Author Contributions: Conceptualization, T.Z. and H.D.; literature search, T.Z., S.L. and A.D.; writing—original draft preparation, T.Z. and S.L.; writing—review and editing, T.Z., S.L., A.D. and H.D.; visualization, T.Z.; funding acquisition, H.D. All authors have read and agreed to the published version of the manuscript.

Funding: This research was funded by the Hebei Province Maize Industry System Project (HBCT2018020207).

Institutional Review Board Statement: Not applicable.

Data Availability Statement: Not applicable.

Acknowledgments: We are highly grateful to Nutrien (https:/ / nutrient-ekonomics.com accessed on 16 January 2021) for granting us permission to reuse their diagram (with slight modifications), to show the sulphur cycle in Figure 2. The diagram was adopted from their website: Sulfur in 
Soil I Nutrien eKonomics I Crop Nutrition Research (nutrien-ekonomics.com). We are also deeply indebted to Smart Fertilizer UK (https: / / www.smart-fertilizer.com/) for granting us permission to reuse two of their photographs in Figure 3 to show visual symptoms of sulphur deficiency in different crop species. The photographs were accessed from their website: https:/ www.smartfertilizer.com/articles/sulfur/ (accessed on 15 September 2020).

Conflicts of Interest: The authors declare no conflict of interest. Further, the authors declare that the funder did not play any role in the design of the study; collection, analyses or interpretation of data; in the writing of the manuscript, or in the decision to publish the results.

\section{References}

1. Food and Agricultural Organization of the United Nations (FAO); UNESCO. Global Agriculture towards 2050. High Level Expert Forum-How to Feed the World in 2050; FAO: Rome, Italy, 12-13 October 2009.

2. Elferink, M.; Schierhorn, F. Global Demand for Food is Rising. Can we meet it. Harv. Bus. Rev. 2016, 7, 2-5.

3. Marschner, P. Mineral Nutrition of Higher Plants, 3rd ed.; Elsevier: New York, NY, USA, 2012.

4. Sahota, T.S. Importance of Sulphur in Crop Production. Ont. Farmer Northwest Link 2012, 46, 11-12. [CrossRef]

5. Bouranis, D.L.; Chorianopoulou, S.N.; Siyiannis, V.F.; Protonotarios, V.E.; Koufos, C.; Maniou, P. Changes in nutrient allocation between roots and shoots of young maize plants during sulphate deprivation. J. Plant Nutr. Soil Sci. 2012, 175, 499-510. [CrossRef]

6. Sienkiewicz-Cholewa, U.; Kieloch, R. Effect of sulphur and micronutrients fertilization yield and fat content in winter rape seeds (Brassica napus L.). Plant Soil Environ. 2015, 61, 164-170. [CrossRef]

7. Kopriva, S.; Malagoli, M.; Takahashi, H. Sulfur nutrition: Impacts on plant development, metabolism, and stress responses. J. Exp. Bot. 2019, 70, 4069-4073. [CrossRef] [PubMed]

8. Xie, R.; Dong, S.; Hu, C.; Wang, K. The role of nitrogen and sulphur interaction in maize quality (Zea mays L.). Agric. Sci. China 2003, 2, 527-532.

9. Tiwari, K.N.; Gupta, B.R. Sulphur for Sustainable High Yield Agriculture in Uttah Pradesh. Indian J. Fertil. 2006, 1, 37-52.

10. Jarvan, M.; Edesi, L.; Adamson, A.; Lukme, L.; Akk, A. The effect of sulphur fertilization yield, quality of protein and baking properties of winter wheat. Agron. Res. 2008, 6, 459-469.

11. Farhad, I.S.M.; Islam, M.N.; Hoque, S.; Bhuiyan, M.S.I. Role of Potassium and Sulphur on the Growth, Yield and Oil Content of Soybean (Glycine max L.). Acad. J. Plant Sci. 2010, 3, 99-103.

12. Rasool, F.U.; Hassan, B.; Jahangir, I.A. Growth and yield of sunflower (Helianthus annus L.) as influenced by nitrogen, sulphur and farmyard manure under temperate conditions. SAARC J. Agric. 2013, 11, 81-89. [CrossRef]

13. Ali, A.; Iqbal, Z.; Hassan, S.W.; Yasin, M.; Khaliq, T.; Ahmed, S. Effect of nitrogen and sulphur on phenology, growth and yield parameters of maize crop. Sci. Int. 2013, 25, 363-366.

14. Nasreen, S.; Imamul Haq, S.M.; Hossain, M.A. Sulphur Effects on Growth, Responses and Yield of Onion. Asian J. Plant Sci 2003, 2, 897-902. [CrossRef]

15. Ullah, M.H.; Huq, S.M.I.; Alam, M.D.U.; Rahman, M.A. Impacts of Sulphur Levels on Yield, Storability and Economic Return of Onion. Bangladesh J. Agric. Res. 2018, 33, 539-548. [CrossRef]

16. Kopriva, S.; Calderwood, A.; Weckopp, S.C.; Koprivova, A. Plant sulphur and Big Data. Plant Sci. 2015, 241, 1-10. [CrossRef] [PubMed]

17. Jamal, A.; Moon, Y.; Abdin, M.Z. Sulphur-A general overview and interaction with nitrogen. Aust. J. Crop Sci. 2010,4 , 523-529. [CrossRef]

18. Nazar, R.; Iqbal, N.; Masood, A.; Syeed, S.; Khan, N.A. Understanding the significance of sulphur in improving salinity tolerance in plants. Environ. Exp. Bot. 2011, 70, 80-87. [CrossRef]

19. Santisree, P.; Adimulam, S.S.; Bommineni, P.; Bhatnagar-Mathur, P.; Sharma, K.K. Hydrogen Sulfide in Plant Abiotic Stress Tolerance: Progress and Perspectives. In Reactive Oxygen, Nitrogen and Sulfur Species in Plants: Production, Metabolism, Signaling and Defense Mechanisms; John Wiley \& Sons: New York, NY, USA, 2019; pp. 743-775.

20. Anjum, N.A.; Gill, S.S.; Umar, S.; Ahmad, I.; Duarte, A.C.; Pereira, E. Improving Growth and Productivity of Oleiferous Brassicas Under Changing Environment: Significance of Nitrogen and Sulphur Nutrition, and Underlying Mechanisms. Sci. World J. Vol. 2012. Available online: http:www.hindawi.com/journals/tswj (accessed on 3 March 2020). [CrossRef] [PubMed]

21. Giordano, M.; Raven, J.A. Nitrogen and Sulfur assimilation in plants and algae. Aquat. Bot. 2014, 118, 45-61. [CrossRef]

22. HARSCO. Sustainable Management of Greens and Tees Under Abiotic Stress. In Cross Over_From Soil to Plant, Product Information Bulletin; HARSCO: Tampa, FL, USA, 2016; Available online: www.numeratortech.com (accessed on 10 October 2020).

23. Edis, R.; Norton, R. Sulphur Nutrition and Fluid Fertilisers. 2012 Victorian Liquid Fertiliser Forum. 2012; p. 4. Available online: http:/ / www.ipni.net/ (accessed on 12 February 2020).

24. Bloem, E. The importance of sulphur in profitable crop production. In Proceedings of the Omnia Farmer's Information Day, Hilton, KwaZulu-Natal, South Africa, 14 August 2015; Phillips, L., Ed.; Farmer's Weekly. 2015. Available online: http: / / farmersweekly.co.za/article.aspx?id=782151 (accessed on 28 November 2019).

25. Matula, J. Barley response to the soil reserve of sulphur and ammonium sulphate in short-term experiments under controlled conditions of cultivation. Plant Soil Environ. 2004, 50, 235-242. [CrossRef] 
26. Messick, D.L. World Sulphur Outlook; The World Sulphur Institute: Washington, DC, USA, 2013; Available online: http:/ /www. firt.org (accessed on 18 April 2020).

27. Chemical Economics Handbook. Sulfur. 2017. Available online: https://ihsmarkit.com/products/sulfur-chemical-economicshandbook.html (accessed on 27 July 2020).

28. Stratistics Market Research Consulting (SMRC). Sulfur Fertilizers-Global Market Outlook (2017-2026) Report; SMRC: Gaithersburg, MD, USA, 2018; p. 173.

29. MarketsandMarkets. Sulfur Fertilizers Market by Type (Sulfates, Elemental Sulfur, Liquid Sulfur Fertilizers), Crop Type (Oilseeds E Pulses, Cereals \& Grains, Fruits \& Vegetables, Others), Mode of Application, Form, Cultivation Type, and Region-Global Forecast to 2025; MarketsandMarkets: New York, NY, USA, 2020; p. 208.

30. Allied Analytics LLP. Sulfur Fertilizers Market by Type, and Type of Agriculture: Global Opportunity Analysis and Industry Forecast, 2019-2026; Allied Analytics LLP: Pune, India, 2020; p. 269.

31. Nickel, R. Price Spike in Sulfur Leaves Farmers, Fertilizer Makers Sour. Commodities. 20 December 2017. Reuters. Available online: https://www.reuters.com/article/us-fertilizers-sulphur-idUSKBN1EE07Q (accessed on 28 July 2020).

32. Mazid, M.; Khan, Z.H.; Quddusi, S.; Khan, T.A.; Mohammad, F. Significance of sulphur nutrition against metal induced oxidative stress in plants. J. Stress Physiol. Biochem. 2011, 7, 165-184. [CrossRef]

33. Mazid, M.; Khan, T.A.; Mohammad, F. Role of secondary metabolites in defense mechanisms of plants. Biol. Med. 2011, 3, 232-249.

34. Till, A.R. Sulphur and Sustainable Agriculture, 1st ed.; International Fertilizer Industry Association: Paris, France, 2010; pp. 1-70.

35. Wiesler, F.; Gerendias, J.; Sattelmacher, B. Influence of mineral fertilizers on nutritional quality of staple food crops. Impacts Agric. Hum. Health Nutr. 2010, 1, 1-36.

36. Zhao, F.; Tausz, M.; De Kok, L.J. Role of Sulfur for Plant Production in Agricultural and Natural Ecosystems. In Sulfur Metabolism in Phototrophic Organisms; Hell, R., Dahl, C., Knaff, D., Leustek, T., Eds.; Advances in Photosynthesis and Respiration; Springer: Dordrecht, The Netherlands, 2008; Volume 27. [CrossRef]

37. Gill, S.S.; Khan, N.A.; Anjum, N.A.; Tuteja, N. Amelioration of cadmium stress in crop plants by nutrients management: Morphological, physiological and biochemical aspects. Plant Stress 2011, 5, 1-23.

38. Hawkesford, M.J.; Dekok, L.J. Managing sulphur metabolism in plants. Plant Cell Environ. 2006, 29, 382-395. [CrossRef] [PubMed]

39. Koprivova, A.; Kopriva, S. Molecular mechanisms of regulation of sulfate assimilation: First steps on a long road. Front. Plant Sci. 2014, 5, 589. [CrossRef]

40. Njira, K.O.W.; Nabwami, J. A review of effects of nutrients elements on crop quality. Afr. J. Food Agric. Nutr. Dev. 2015, 15, 9777-9793.

41. Hell, R.; Khan, M.S.; Wirtz, M. Cellular biology of sulfur and its functions in plants. In Cell Biology of Metals and Nutrients; Hell, R., Mendel, R.-R., Eds.; Plant Cell Monographs; Springer: Berlin/Heidelberg, Germany, 2010; Volume 17, pp. 243-279. [CrossRef]

42. Clarkson, D.T.; Hanson, J.B. The mineral nutrition of higher plants. Annu. Rev. Plant Physiol. 1980, 31, 239-298. [CrossRef]

43. Aulakh, M.S. Crop responses to sulphur nutrition. In Sulphur in Plants; Abrol, Y.P., Ahmad, A., Eds.; Kluwer Academic Publishers: Dordrecht, The Netherlands, 2003; pp. 341-358.

44. Hassan, F.; Manaf, A.; Qadir, G.; Basra, S.M.A. Effects of Sulphur on Seed Yield, Oil, Protein and Glucosinolates of Canola Cultivars. Int. J. Agric. Biol. 2007, 9, 504-508.

45. Scherer, H.W. Sulphur in crop production-Invited paper. Eur. J. Agron. 2001, 14, 81-111. [CrossRef]

46. Kowalska, I. Effects of sulphate level in the nutrient solution plant growth and sulphur content in tomato plants. Folia Hortic. Ann. 2005, 17, 91-100. [CrossRef]

47. El Sayed, H.E.; Hameda, E.A.; El-Morsy, H.A.E.; Hanan, S.A.O. The Role of Sulphur and Certain Foliar Spray Levels of Micro-nutrients on Garlic (Allium sativum L.) Plant. Int. J. Curr. Res. Biosci. Plant Biol. 2015, 2, 76-87.

48. Smatanova, M.; Richter, R.; Hlušek, J. Spinach and pepper response to nitrogen and sulphur fertilization. Plant Soil Environ. 2004, 7, 303-308. [CrossRef]

49. Singh, Y.; Singh, T.; Singh, U.N.; Rajput, T.K. Effect of nutrient management on yield, quality an economics of irrigated Indian mustard (Brassica juncea). Indian J. Agric. Sci. 2010, 80, 691-694. [CrossRef]

50. Fuentes-Lara, L.O.; Medrano-Macías, J.; Pérez-Labrada, F.; Rivas-Martínez, E.N.; García-Enciso, E.L.; González-Morales, S.; Juárez-Maldonado, A.; Rincón-Sánchez, F.; Benavides-Mendoza, A. From Elemental Sulfur to Hydrogen Sulfide in Agricultural Soils and Plants. Molecules 2019, 24, 2282. [CrossRef]

51. Eriksen, J. Chapter 2 Soil sulfur cycling in temperate agricultural systems. Adv. Agron. 2009, 102, 55-89. [CrossRef]

52. Nikiforova, V.J.; Gakiere1, B.; Kempa, S.; Adamik, M.; Willmitzer, L.; Hesse, H.; Hoefgen, R. Towards dissecting nutrient metabolism in plants: A systems biology case study on sulphur metabolism. J. Exp. Bot. 2004, 55, 1861-1870. [CrossRef]

53. Scherer, H.W. Sulfur in Soils. J. Plant Nutr. Soil Sci. 2009, 172, 326-335. [CrossRef]

54. Landers, D.H.; David, M.B.; Mitchell, M.J. Analysis of Organic and Inorganic Sulfur Constituents in Sediments, Soils and Water. Int. J. Environ. Anal. Chem. 1983, 14, 245-256. [CrossRef]

55. Peplow, M. Sulphur from soil. Nature 2004, 428, 136. Available online: www.nature.com/nature (accessed on 3 May 2019).

56. Germida, J.J.; Siciliano, S.D. Sulfur Cycle in Soils. In Encyclopedia of Environmental Microbiology; Bitton, G., Ed.; John Wiley \& Sons: New York, NY, USA, 2003. [CrossRef]

57. Gunjal, A.B.; Waghmode, M.S.; Patil, N.N.; Nawani, N.N. Significance of soil enzymes in agriculture. In Smart Bioremediation Technologies; Academic Press: New York, NY, USA, 2019; pp. 159-168. [CrossRef] 
58. Tabatabai, M.A.; Bremner, J.A. Arylsulfatase activity of soils. Soil Sci. Soc. Am. Proc. 1970, 34, 225-229. [CrossRef]

59. Brüser, T.; Lens, P.; Trüper, H.G. The biological sulfur cycle. In Environmental Technologies to Treat Sulfur Pollution; Lens, P., Pol, L.H., Eds.; IWA Publishing: London, UK, 2000; pp. 47-86.

60. Westley, J.; Adler, H.; Westley, L.; Nishida, C. The sulfurtransferases. Fundam. Appl. Toxicol. 1984, 3, 377-382. [CrossRef]

61. Buchner, P.; Stuiver, C.E.; Westerman, S.; Wirtz, M.; Hell, R.; Hawkesford, M.J.; De Kok, L.J. Regulation of sulfate uptake and expression of sulfate transporter genes in Brassica oleracea as affected by atmospheric $\mathrm{H}(2) \mathrm{S}$ and pedospheric sulfate nutrition. Plant Physiol. 2004, 136, 3396-3408. [CrossRef] [PubMed]

62. Droux, M. Sulfur assimilation and the role of sulfur in plant metabolism: A survey. Photosynth. Res. 2004, 79, 331-348. [CrossRef]

63. Davidian, J.C.; Kopriva, S. Regulation of sulfate uptake and assimilation-The same or not the same? Mol. Plant 2010, 3, 314-325. [CrossRef]

64. Kopriva, S.; Koprivova, A. Sulphate assimilation and glutathione synthesis in C4 plants. Photosynth. Res. 2005, 86, 363-372. [CrossRef]

65. Khan, N.A.; Khan, M.I.R.; Asgher, M.; Fatma, M.; Masood, A.; Syeed, S. Salinity Tolerance in Plants: Revisiting the Role of Sulfur Metabolites. J. Plant Biochem. Physiol. 2014, 2. [CrossRef]

66. Takahashi, H.; Yamazaki, M.; Sasakura, N.; Watanabe, A.; Leustek, T.; Engler, J.A.; Engler, G.; Van Montagu, M.; Saito, K. Regulation of sulfur assimilation in higher plants: A sulfate transporter induced in sulphate starved roots plays a central role in Arabidopsis thaliana. Proc. Natl. Acad. Sci. USA 1997, 94, 11102-11107. [CrossRef] [PubMed]

67. Takahashi, H. The roles of three functional sulphate transporters involved in uptake and translocation of sulphate in Arabidopsis thaliana. Plant J. 2000, 23, 171-182. [CrossRef] [PubMed]

68. Takahashi, H.; Kopriva, S.; Giordano, M.; Saito, K.; Hell, R. Sulfur assimilation in photosynthetic organisms: Molecular functions and regulations of transporters and assimilatory enzymes. Annu. Rev. Plant Biol. 2011, 62, 157-184. [CrossRef]

69. Saito, K. Sulfur Assimilatory Metabolism. The Long and Smelling Road. Update on Nutrient Metabolism. Plant Physiol. 2004, 136, 2443-2450. [CrossRef]

70. Maruyama-Nakashita, A.; Inoue, E.; Watanabe-Takahashi, A.; Yamaya, T.; Takahashi, H. Transcriptome Profiling of SulfurResponsive Genes in Arabidopsis Reveals Global Effects of Sulfur Nutrition Multiple Metabolic Pathways. Plant Phys. 2003, 132, 597-605. [CrossRef]

71. Prioretti, L.; Gontero, B.; Hell, R.; Giordano, M. Diversity and regulation of ATP sulfurylase in photosynthetic organisms. Front. Plant Sci. 2014, 5597, 1-12. [CrossRef]

72. Kopriva, S.; Rennenberg, H. Control of sulphate assimilation and glutathione synthesis: Interaction with $\mathrm{N}$ and $\mathrm{C}$ metabolism. $J$ Exp. Bot. 2004, 55, 1831-1842. [CrossRef] [PubMed]

73. Aubry, S.; Smith-Unna, R.D.; Boursnell, C.M.; Kopriva, S.; Hibberd, J.M. Transcript residency on ribosomes reveals a key role for the Arabidopsis thaliana bundle sheath in sulfur and glucosinolate metabolism. Plant J. 2014, 78, 659-673. [CrossRef] [PubMed]

74. Lappartient, A.G.; Touraine, B. Demand-driven control of root ATP sulphurylase activity and SO2 4 uptake in intact canola. The role of phloem-translocated glutathione. Plant Physiol. 1996, 111, 147-157. [CrossRef]

75. Leustek, T.; Martin, M.N.; Bick, J.A.; Davies, J.P. Pathways and regulation of sulfur metabolism revealed through molecular and genetic studies. Annu. Rev. Plant Phys. 2000, 51, 141-165. [CrossRef] [PubMed]

76. Singh, M.; Srivastava, R.; Verma, K.K. Biological sulfur acquisition: An update. Elixir Appl. Bot. 2013, 62, $17740-17747$.

77. Honsel, A.; Kojima, M.; Haas, R.; Frank, W.; Sakakibara, H.; Herschbach, C.; Rennenberg, H. Sulphur limitation and early sulphur deficiency responses in poplar: Significance of gene expression, metabolites, and plant hormones. J. Exp. Bot. 2012, 63, 1873-1893. [CrossRef]

78. Kawashima, C.G.; Yoshimoto, N.; Maruyana-Nakashita, A.; Tsuchiya, Y.N.; Saito, K.; Takahashi, H.; Dalmayl, T. Sulphur starvation induces the expression of microRNA-395 and one of its target genes but in different cell types. Plant J. 2009, 57, 313-321. [CrossRef]

79. Kaya, M.; Küçükyumuk, Z.; Erdal, I. Effects of elemental sulfur and sulfur-containing waste on nutrient concentrations and growth of bean and corn plants grown on calcareous soil. AJB 2009, 8, 4481-4489. [CrossRef]

80. Janzen, H.H.; Bettany, J.R. Sulfur nutrition of rapeseed: I. Influence of fertilizer nitrogen and sulfur rates. Soil Sci. Soc. Am. J. 1984, 48, 100-107. [CrossRef]

81. Wardman, J. Don't Forget about Sulphur. Yara. UK. Available online: https://www.yara.co.uk/crop-nutrition/agronomyadvice/dont-forget-about-sulphur/ (accessed on 25 August 2020).

82. Dev, G.; Kumar, V. Secondary nutrients. In Review of Soil Research in India, Part I, 12th International Congress on Soil Science, (SS' 82); Indian Society of Soil Science: New Delhi, India, 1982; pp. 342-360.

83. Potash Development Association. Sulphur as a Nutrient for Crops and Grass. 2017. Available online: https://www.pda.org.uk/ sulphur-nutrient-crops-grass / (accessed on 25 August 2020).

84. Fismel, S.; Vong, P.C.; Guckert, A.; Frossard, E. 'Influence of sulfur on apparent N-uses efficiency, yield and quality of oilseed rape (Brassica napus L.) grown on a calcareous soil. Eur. J. Agron. 2000, 12, 127-141. [CrossRef]

85. McGrath, S.P.; Zhao, F.J. Sulphur uptake, yield responses and the interactions between nitrogen and sulphur in winter oilseed rape (Brassica napus). J. Agric. Sci. 1996, 126, 53-62. [CrossRef] 
86. Ahmad, A.; Abraham, G.; Gandotra, N.; Abrol, Y.P. Interactive effect of nitrogen and sulphur on growth and yield of rapeseedmustard (Brassica juncea L. Czern and Coss. and Brassica compestris L.) genotypes. J. Agron. Crop Sci. 1998, 181, 193-199. [CrossRef]

87. Jamal, A.; Fazil, I.S.; Ahmad, S.; Abdin, M.Z.; Song, J.Y. Effect of Sulphur and Nitrogen Application Growth Characteristics, Seed and Oil Yields of Soybean Cultivars. Korean J. Crop Sci. 2005, 50, 340-345.

88. Jamal, A.; Fazil, I.S.; Ahmad, S.; Abdin, M.Z. Interactive Effect of Nitrogen and Sulphur on Yield and Quality of Groundnut (Arachis hypogea L.). Korean J. Crop Sci. 2006, 51, 519-522.

89. Clarkson, D.T.; Saker, L.R.; Purves, J.V. Depression of nitrate and ammonium influx in barley plants with diminished sulphatestatus. Evidence for co-regulation in nitrogen and sulphate intake. J. Exp. Bot. 1989, 40, 953-963. [CrossRef]

90. Fazili, I.S.; Masoodi, M.; Ahmad, S.; Jamal, A.; Khan, J.S.; Abdin, M.Z. Interactive Effects of Sulfur and Nitrogen on Growth and Yield Attributes of Oilseed Crops (Brassica campestris L. and Eruca sativa Mill.) Differing in Yield Potential. J. Plant. Nutr. Soil Sci. 2010, 33, 1216-1228. [CrossRef]

91. Salvagiotti, F.; Miralles, D.J. Radiation interception, biomass production and grain yield as affected by the interaction of nitrogen and sulfur fertilization in wheat. Eur. J. Agron. 2008, 28, 282-290. [CrossRef]

92. Hocking, P.J.; Randal, P.J.; Pinkerton, A. Sulfur nutrition of sunflower (Helianthus annus) as affected by nitrogen supply. Effects on vegetative growth, development of yield components, and seed yield and quality. Field Crops Res. 1987, 16, 157-175. [CrossRef]

93. Patra, P.; Pati, B.K.; Ghosh, G.K.; Mura, S.S.; Saha, A. Effect of Biofertilizers and Sulphur on Growth, Yield, and Oil Content of Hybrid Sunflower (Helianthus annuus L.) In a Typical Lateritic Soil. J. Bacteriol. Parasitol. 2013, 2, 603. [CrossRef]

94. Raza, M.A.; Feng, L.Y.; Manaf, A.; Wasaya, A.; Ansar, M.; Hussain, A.; Khalid, M.H.; Iqbal, N.; Xi, Z.J.; Chen, Y.K.; et al. Sulphur application increases seed yield and oil content in sesame seeds under rainfed conditions. Field Crops Res. 2018, 218, 51-58. [CrossRef]

95. Abdin, M.Z.; Ahmad, A.; Khan, N.; Khan, I.; Jamal, A.; Iqbal, M. Sulphur Interaction with Other Nutrients. In Sulphur Plants; Abrol, Y.P., Ahmad, A., Eds.; Springer: Dordrecht, The Netherlands, 2003; pp. 359-374. [CrossRef]

96. Alam, A.K.M.M.; Goni, M.N.; Rahman, M.M.; Islam, M.N.; Hussain, M.S. Individual and interaction effect of macro and micronutrients on jute seed production. Int. J. Sustain. Crop. Prod. 2009, 4, 22-26.

97. Yadav, B.K. Interaction Effect of Phosphorus and Sulphur on Yield and Quality of Clusterbean in Typic Haplustept. World J. Agric. Sci. 2011, 7, 556-560.

98. Dash, A.K.; Singh, H.K.; Mahakud, T.; Pradhan, K.C.; Jena, D. Interaction Effect of Nitrogen, Phosphorus, Potassium with Sulphur, Boron and Zinc on Yield and Nutrient Uptake by Rice Under Rice-Rice Cropping System in Inceptisol of Coastal Odisha. Int. Res. J. Agric. Sci. Soil Sci. 2015, 5, 14-21.

99. Anonymous. Phosphorus improves crop quality. Better Crops 1999, 83, 2829.

100. Islam, M.; Ali, S.; Hayat, R. Effect of Integrated Application of Phosphorus and Sulphur on Yield and Micronutrient Uptake by Chickpea (Cicer arietinum). Int. J. Agric. Biol. 2009, 11, 33-38.

101. Saha, B.; Saha, S.; Saha, R.; Hazra, G.C.; Mandal, B. Influence of Zn, B and S on the yield and quality of groundnut (Arachis Hypogea L.). Legume Res. 2015, 38, 832-836.

102. Anjum, N.A.; Gill, R.; Kaushik, M.; Hasanuzzaman, M.; Pereira, E.; Ahmad, I.; Tuteja, N.; Gill, S.S. ATP-sulfurylase, sulfurcompounds, and plant stress tolerance. Front. Plant Sci. 2015, 6, 210. [CrossRef] [PubMed]

103. Gill, S.S.; Tuteja, N. Reactive oxygen species and antioxidant machinery in abiotic stress tolerance in crop plants. Plant Physiol. Biochem. 2010, 48, 909-930. [CrossRef]

104. Anjum, N.A.; Umar, S.; Chan, M.T. Ascorbate-Glutathione Pathway and Stress Tolerance in Plants; Springer: Dordrecht, The Netherlands, 2010. [CrossRef]

105. Rais, L.; Masood, A.; Inam, A.; Khan, N. Sulfur and Nitrogen Co-ordinately Improve Photosynthetic Efficiency, Growth and Proline Accumulation in Two Cultivars of Mustard Under Salt Stress. J. Plant Biochem. Physiol. 2013, 1, 101. [CrossRef]

106. Fatma, M.; Asgher, M.; Masood, A.; Khan, N.A. Excess sulfur supplementation improves photosynthesis and growth in mustard under salt stress through increased production of glutathione. Environ. Exp. Bot. 2014, 107, 55-63. [CrossRef]

107. Bystrická, J.; Kavalcová, P.; Vollmannová, A.; Tomáš, J.; Orsák, M. The Role of Sulphur on the Content of Total Polyphenols and Antioxidant Activity in Onion (Allium cerpa L.). Potravin. Sci. J. Food Ind. 2014, 8, 284-289. [CrossRef]

108. Noctor, G.; Arisi, A.-C.M.; Jouanin, L.; Kunert, K.J.; Rennenberg, H.; Foyer, C.H. Glutathione: Biosynthesis, metabolism and relationship to stress tolerance explored in transformed plants. J. Exp. Bot. 1998, 49, 623-647. [CrossRef]

109. Khan, I.; Ahmad, A.; Iqbal, M. Modulation of antioxidant defence system for arsenic detoxification in Indian mustard. Ecotoxicol. Environ. Saf. 2009, 72, 626-634. [CrossRef]

110. Anjum, N.A.; Aref, I.M.; Duarte, A.C.; Pereira, E.; Ahmad, I.; Iqbal, M. Glutathione and proline can coordinately make plants withstand the joint attack of metal (loid) and salinity stresses. Front. Plant Sci. 2014, 5, 662. [CrossRef] [PubMed]

111. Talukdar, D.; Talukdar, T. Coordinated response of sulfate transport, cysteine biosynthesis, and glutathione-mediated antioxidant defense in lentil (Lens culinaris Medik.) genotypes exposed to arsenic. Protoplasma 2014, 251, 839-855. [CrossRef]

112. Noji, M.; Saito, K. Metabolic engineering of sulphur assimilation in plants. In Applications of Plant Metabolic Engineering; Verpook, R., Alfermann, A.W., Johnson, T.S., Eds.; Springer: Dordrecht, The Netherlands, 2007; pp. 297-309.

113. Astolfi, S.; Zuchi, S. Adequate sulfur supply protects barley plants from adverse effects of salinity stress by increasing thiol contents. Acta Physiol. Plant 2013, 35, 175-181. [CrossRef] 
114. Romero, L.C.; Domínguez-Solís, J.R.; Gutiérrez-Alcalá, G.; Gotor, C. Salt regulation of O-acetylserine (thiol) lyase in Arabidopsis thaliana and increased tolerance in yeast. Plant Physiol. Biochem. 2001, 39, 643-647. [CrossRef]

115. Fediuc, E.; Lips, S.H.; Erdei, L. O-actylserine (thiol) lyase activity in Phyragmites and Typha plants under cadium and NaCl stress conditions and the involvement of ABA in the stress response. J. Plant Physiol. 2005, 162, 865-872. [CrossRef] [PubMed]

116. Ruiz, J.M.; Blumwald, E. Salinity induced glutathione synthesis in Brassica napus. Planta 2002, 214, 965-969. [CrossRef] [PubMed]

117. Schnug, E. Physiological functions and environmental relevance of sulfur-containing secondary metabolites. In Sulfur Nutrition and Sulfur Assimilation in Higher Plants: Regulatory, Agricultural and Environmental Aspects; De Kok, L.J., Stulen, I., Rennenberg, H., Brunold, C., Rauser, W., Eds.; SPB Academic: The Hague, The Netherlands, 1993; pp. 179-190.

118. Randle, W.M.; Lancaster, J.E. Sulphur compounds in Alliums in relation to flavour quality. In Allium Crop Science: Recent Advances; Rabinowitch, H.D., Currah, L., Eds.; CAB International Wallingford: Wallingford, UK, 2002; pp. 329-356.

119. Lancaster, J.E.; Collin, H.A. Presence of alliinase in isolated vacuoles and of alkyl cysteine sulphoxides in the cytoplasm of bulbs of onion (Allium cepa). Plant Sci. Lett. 1981, 22, 169-176. [CrossRef]

120. Hell, R.; Kruse, C. Sulfur in biotic interactions of plants. In Sulfur in Plants-An Ecological Perspective; Hawkesford, M.J., De Kok, L.J., Eds.; Springer: Cham, Switzerland, 2007; pp. 197-224.

121. Khan, T.A.; Mazid, M. Nutritional significance of sulphur in pulse cropping system. Biol. Med. 2011, 3, 114-133. [CrossRef]

122. Koca, Y.O.; Canavar, Ö.; Kaptan, M.A. Changes of seed yield and quality of maize (Zea mays L.) fertilized with sulphur in early and late sowing date. In Proceedings of the 9th International Soil Science Congress on 'The Soul of Soil and Civilization', Side, Antalya, Turkey, 14-16 October 2014; Soil Science Society of Turkey \& Federation of Eurasian Soil Science Societies: Antalya, Turkey, 2014; pp. 1002-1007.

123. Channabasamma, A.; Habsur, N.S.; Bangaremma, S.W.; Akshaya, M.C. Effect of Nitrogen and Sulphur Levels and Ratios on Growth and Yield of Maize. Mol. Plant Breed. 2013, 4, 292-296. [CrossRef]

124. Jeet, S.; Singh, J.P.; Kumar, R.; Kumar, P.R.; Kumar, P.; Kumari, A.; Prakash, P. Effect of Nitrogen and Sulphur Levels on Yield, Economics and Quality of QPM Hybrids under Dryland Conditions of Eastern Uttar Pradesh, India. J. Agric. Sci. 2012, 4, 31-38. [CrossRef]

125. Malavolta, E.; Vitti, G.C.; Rosolem, C.A.; Fageria, N.K.; Guimarães, P.T.G. Micronutrients. J. Plant Nutr. 1987, 10, 2153-2158. [CrossRef]

126. Mathot, M.; Mertens, J.; Verlinden, G.; Lambert, R. Positive effect of sulphur fertilisation grasslands yields and quality in Belgium. Eur. J. Agron. 2008, 28, 655-658. [CrossRef]

127. Zenda, T.; Yao, D.; Duan, H. Sulphur and chlorine effects on yield and quality in fresh corn. Int. J. Plant Soil Sci. 2017, 18, 1-10. [CrossRef]

128. Tao, Z.; Chang, X.; Wang, D.; Wang, Y.; Ma, S.; Yang, Y.; Zhao, G. Effects of sulfur fertilization and short-term high temperature on wheat grain production and wheat flour proteins. Crop J. 2018, 6, 413-425. [CrossRef]

129. Uchida, R. Essential Nutrients for Plant Growth: Nutrient Functions and Deficiency Symptoms. In Plant Nutrient Management in Hawaii's Soils, Approaches for Tropical and Subtropical Agriculture; Silva, J.A., Uchida, R., Eds.; College of Tropical Agriculture and Human Resources, University of Hawaii at Manoa: Honolulu, HI, USA, 2000; pp. 1-55.

130. Schnug, E.; Haneklaus, S. Diagnosis of Sulphur Nutrition. In Sulphur in Agroecosystems; Schnug, E., Ed.; Kluwer Academic Publishers: Dordrecht, The Netherlands, 1998; pp. 1-38. [CrossRef]

131. Mikkelsen, R.; Norton, R. Soil and Fertilizer Sulfur. Better Crops 2013, 97, 7-9.

132. Saskatchewan. Sulphur Fertilization in Crop Production. 2020. Available online: https://www.saskatchewan.ca/business/ agriculture-natural-resources-and-industry/agribusiness-farmers-and-ranchers/crops-and-irrigation/soils-fertility-andnutrients/sulphur-fertilization-in-crop-production (accessed on 2 September 2020).

133. Tandon, H.L.S. Sulphur Research and Agricultural Production in India, 3rd ed.; The Sulphur Institute: Washington, DC, USA, 1991; pp. 257-343.

134. Ohkama-Ohtsu, N.; Wasaki, J. Recent Progress in Plant Nutrition, Research: Cross-Talk Between Nutrients, Plant Physiology and Soil Microorganisms. Plant Cell Physiol. 2010, 51, 1255-1264. [CrossRef] [PubMed]

135. Li, D.; Li, C.; Yao, Y.; Li, M.; Liu, L. Modern imaging techniques in plant nutrition analysis: A review. Comput. Electron. Agric. 2020, 174, 105459. [CrossRef] 